\title{
The Social Liminality of Musicians: Case Studies from Mughal India and Beyond
}

\author{
KATHERINE BUTLER BROWN
}

\begin{abstract}
This paper offers a new, cross-cultural paradigm for understanding the location of professional musicians in modern social hierarchies. Basing my argument on Victor Turner's theories of liminality and on primary-source research on North Indian musicians in the Mughal empire (c. 1658-1858), I maintain that professional musicians in most, if not all, societies possess institutionally liminal status. Although the occupation of 'musician' is relatively low, being essentially both service profession and cultural labour, the cultural capital that accrues to the product of their labour - their music - enables musicians to cross over into higher-status spaces, to mingle on more equal terms with their patrons, and, in the moment of performance, to exercise power over them. While this may offer opportunities of permanent social elevation for the best performers, in many societies patrons may apply subtle social sanctions to those who attempt to overstep the boundaries, in order to keep musicians in their place. While this hypothesis has clear resonances with Merriam's famous tripartite formulation of low status/high importance/tolerance of 'deviance', institutional liminality also makes sense of the puzzling exceptions to his rule.
\end{abstract}

For many years I was to be virtually rootless in the world - a stranger in the white world, of course, for color must keep you forever a stranger there - but also a stranger in the world which most Negroes inhabit and with which they are forced, from birth, to come to terms. Neither world was ever to be totally mine because I would never stay long enough in either of them to acquire that intimate, bred-in-the-bones knowledge of them that comes from having roots so deep that you cannot see or even trace some of them.

Lena Horne $e^{1}$

Prophets and artists tend to be liminal and marginal people, 'edgemen'.

Victor Turner ${ }^{2}$

\section{Forever a Stranger: The Puzzle of Musicians' Social Location}

According to the ancient customs of the social sciences and humanities, it is traditional to begin any paper, particularly one that seeks to theorize a 'new' concept on older but still serviceable foundations, with a series of ritual invocations to the ancestors. ${ }^{3}$ In writing about

1 Horne and Schickel, Lena, 3.

2 Turner, Ritual Process, 128.

3 I wish to acknowledge several people who helped make this paper a better piece of scholarship, particularly Laudan Nooshin and Jim Kippen, but also comments from Stephen Cottrell and Dai Griffiths. I am grateful, too, to Gage 
the social status of musicians - by which I mean rank in the overall social hierarchy - it has long been customary to invoke the name of that great ancestral ethnomusicologist Alan Merriam. In 1964 Merriam published his magnum opus The Anthropology of Music, in which he included a detailed examination of the status and functions of musicians in society; this examination, which is notable for its cross-cultural breadth and wide theoretical applicability, remains unsurpassed. The impact of this foregrounding of the performer as a central focus of musicological study has, however, been somewhat patchy. Until the late 1990s, apart from popular biographies of artists such as Yehudi Menuhin or Arthur Rubinstein, ${ }^{4}$ most of which have few pretensions to academic status, scholarly studies of performers in Western art music were comparatively rare..$^{5}$ By contrast, there has been a constant stream of ethnomusicological studies and popular music studies of musicians as individuals, as social groups, and as members of society overall. ${ }^{6}$ Approaching musical cultures through the social relations of performers even seems to have become paradigmatic in the study of certain musical traditions, notably those of South Asia. ${ }^{7}$

Merriam's classic, paradoxical hypothesis that musicians in many societies are of 'low status and high importance', in whom, furthermore, 'deviant behavior [may be] not only tolerated but also admired', ${ }^{8}$ is at least invoked in nearly all ethnomusicological studies of musicians, and has been taken up as a model to be tested by a number of them. ${ }^{9}$ Howard Becker's exactly contemporary (1963) definition of 'deviance' is of value to our understanding of Merriam's thought on the subject:

Social groups create deviance by making the rules whose infraction constitutes deviance, and by applying those rules to particular people and labeling them as outsiders [...] deviance is not a quality of the act the person commits, but rather a consequence of the application by others of rules and sanctions to an 'offender'. The deviant is one to whom that label has successfully been applied; deviant behavior is behavior that people so label. ${ }^{10}$

Averill and Ellen Koskoff, my co-organizers of a panel on liminality at IMS Melbourne in 2004, and to Michael Bywater for many stimulating conversations on the subject; these interactions enabled me to hone my initial thoughts. Any errors or unacceptably wild speculations are, of course, my own.

4 For example, Rolfe, The Menuhins; Sachs, Arthur Rubinstein.

5 See Russell, 'Musicians in the English Provincial City', 233. I am discounting the large number of studies in which the word 'musician' is misleadingly used as a synonym for 'composer'. I discern a distinction in Western art music after Beethoven between composers, i.e. those who create, and 'musicians' - meaning performers - who merely reproduce someone else's creation (on conductors see also Adorno, Introduction to the Sociology of Music, 104, 110-11). Important exceptions include Ehrlich, particularly The Music Profession in Britain; the contributions of Olleson, Russell, and Gillett to Music and British Culture; and Cottrell's Professional Music-Making in London.

6 See, for example, in ethnomusicology: Neuman, Life of Music in North India; Baily, Music of Afghanistan; Kippen, Tabla of Lucknow; Doubleday, Three Women of Herat; Rice, May It Fill your Soul; van Nieuwkerk, 'A Trade Like Any Other'; and Danielson, Voice of Egypt; see also Cottrell, Professional Music-Making, 7.

7 Neuman's Life of Music is the paradigmatic study in this respect, but there are many others, including several monographs written or co-written by professional classical performers; see, for example, Shankar, My Music, My Life; Sorrell and Narayan, Indian Music in Performance; Sanyal and Widdess, Dhrupad; and Viswanathan and Allen, Music in South India.

8 Merriam, Anthropology of Music, 137.

9 For example, Baily, Music of Afghanistan, 103; Cottrell, Professional Music-Making, 29-30.

10 Becker, Outsiders, 9. 
Indeed, there is a great deal of cross-cultural evidence to support Merriam's thesis, particularly if one takes the term 'low status' to include 'outsiders' - people belonging to marginal (or marginalized) communities, such as ethnic minorities. To make this point, one has only to consider the enormous importance of Jewish musicians, particularly piano and violin virtuosi, to the history of Western art music; or the successful penetration of all kinds of music and musicians of African-American origin into mainstream popular culture in the United States, even during the era of segregation; or the central role of Romani musicians in Eastern European societies; ${ }^{11}$ or the significance of blind musicians in a number of cultures - Ukraine and Japan, for example, and even the Blind Boys of Alabama.

But I want to begin my evaluation of the social location of musicians by approaching Merriam's hypothesis from a slightly unorthodox angle. I should first point out that my argument will be largely confined to live performance contexts - situations where musicians are physically present. Secondly, my use of the term 'musicians' will be restricted to 'professional musicians' - people who earn most or all of their living from musical performance and are therefore reliant on patronage of one kind or another for economic survival. I am aware of the somewhat interminable debate in ethnomusicology about the usefulness of the term 'professional musician', ${ }^{12}$ but I have adopted it in this paper for two reasons: first, and primarily, because I wish to argue that in societies where 'musician' is recognized as a potential occupational category, a distinct social-rank difference between 'professional' and 'amateur' or 'non-' musicians is indeed customarily recognized; and secondly, in part, because my hypothesis grows out of my work on the world of Indian classical music, where musical specialists have for centuries been full-time and paid, and where professionalization along post-industrial European lines since the late nineteenth century has involved significant changes to these musicians' social position.

On closer examination, it is interesting to note that Merriam's initial discussion of the social location of musicians, rather than presenting his formulation as a neatly defined package, is marked by a degree of puzzlement. In laying out the parameters to be discussed in his chapter on musicians, he at first suggests that musicians' 'status may be high or low or a combination of both'. ${ }^{13}$ As a caveat, perhaps, to his final formulation, he thus makes room for the idea that musical specialists in some societies may, instead, be of high status. Indeed, a number of social theorists and writers on music have shared this view of musicians' social rank, particularly in relation to performers of art or classical music. Bourdieu, for example, in Distinction, his seminal study of the relationship between social class and cultural capital, places 'art producers' in his highest social-class category, ${ }^{14}$ and includes them alongside the intelligentsia as one of his three 'sub-groups of the ruling class', the other two being owners

11 See the article by Hooker in this issue.

12 The debate concerns the artificiality of a distinction between 'professional' and 'amateur' status, given that in some societies those who are paid are considered worse musicians than those who are not, and even those who are paid may derive their principal income from non-musical work. It is usually agreed that professional/amateur is a continuum rather than a dichotomy, and that 'specialist' is perhaps a better term than 'professional' (Merriam, Anthropology of Music, 125-7; for a longer discussion see Cottrell, Professional Music-Making, 9-11).

13 Merriam, Anthropology of Music, 123.

14 Bourdieu, Distinction, 17. 
of large companies and independent professionals. ${ }^{15}$ Gramsci, too, in formulating his theory that each class of society produces its own distinctive sub-class of intellectuals, ${ }^{16}$ argues that 'the creators of the various sciences, philosophy, art, etc.' come from the 'highest' of his three 'great social levels', that of 'the big landowners' ${ }^{17}$ In her salacious memoir of her exploits as an orchestral oboe player, Blair Tindall voices some commonly held views specifically related to European art music: that classical music is a 'glamorous' profession, and that orchestral musicians are (or should be) of the same rank as doctors, lawyers, and university professors. ${ }^{18}$ It is also customarily assumed in studies of Indian classical music that solo vocalists and instrumentalists are considered by both their patrons and wider society to be of high social rank, even to the point of taking their place among the aristocracy. ${ }^{19}$ And other scholars seem to have used Merriam's caveat to allow for distinctions between different classes of professional musician in the society they study, of whom some apparently conform to his 'low status/high importance' formulation, while others come from indisputably higher-class backgrounds. ${ }^{20}$

Merriam, too, goes on to present examples of musicians whom he or his secondary sources consider to be of 'definite' high status in their societies. However, it is also in the context of these examples of apparent high status that we first encounter Merriam's puzzlement over the precise nature of musicians' social location. He hesitates before presenting them, noting that the issue of musicians' location is problematic, '[often] not a simple and clear-cut proposition of either high or low'. And although he presents the Ibo musicians of Nigeria as 'definite' proof that some musicians possess high status, using as evidence the fact that 'instrumental soloists [...] are treated with great respect, their services are in demand and their reward is generally liberal [...] many artists become very popular [and are accorded great honour]', he also distrusts this, noting that 'it is often difficult to tell precisely

15 Honneth, 'Fragmented World', 13. One needs to bear in mind that Bourdieu's research was undertaken in France, where the surviving traditional aristocracy is tiny and far less powerful than its British counterpart; it is difficult to understand, however, why government has no place in his vision of the ruling classes.

Gramsci, Prison Notebooks, in Crehan, Gramsci, Culture and Anthropology, 135-6. It is commonly assumed that Gramsci posits intellectuals as a mediating group between the ruling and subaltern classes that acts to enforce hegemonic ideologies throughout society largely by the power of attraction rather than force. While this notion can be distilled from some of his statements (e.g. Gramsci, in Crehan, Gramsci, Culture and Anthropology, 134), it is a mischaracterization of his complex argument about the relationship of intellectuals to hegemony, given his basic premise that all social classes have their own intellectual sub-class. Crehan's valuable reassessment, from the original sources, of Gramsci's understanding of culture in relation to class demonstrates some fundamental misunderstandings in the humanities and social sciences of Gramsci's concept of 'hegemony' in relation to ideological and intellectual endeavour. She blames this on scholars' reliance on Raymond Williams's convenient gloss of Gramscian hegemony in Marxism and Literature (Gramsci, Culture and Anthropology, 167), but I suspect the greater impact on the creation of what she calls 'hegemony lite' in anthropology and cultural studies was Said's confusion of Gramscian hegemony with Foucauldian discourse theory in Orientalism (see Porter, 'Orientalism', 150-3), and later uses of hegemony by his influential followers such as Homi Bhabha.

17 Crehan, Gramsci, Culture and Anthropology, 140, 136-7.

18 Tindall, Mozart in the Jungle, 215, 157, 226. Ehrlich notes that this insistence has been loudly repeated by professional musicians since at least the nineteenth century (Music Profession, 129, 154); for similar self-assessments see also Cottrell, Professional Music-Making, 194.

19 See Miner, Sitar and Sarod, 80; for the stereotypical view of biographers see also Bakhle, Two Men and Music, 33.

20 For example, Baily on Afghan musicians (Music in Afghanistan, 102-3). But for a considerably lower opinion of the social rank of Western orchestral musicians see Adorno, Introduction to the Sociology of Music, 110-11. 
what is meant by "respect" or "reverence", and it is to be suspected that the picture is much more complicated than might appear'. ${ }^{21}$ Merriam's puzzlement finds an echo in the perplexed responses of Tindall and Allyn Miner, who, contrary to their assumptions, are each confronted with evidence that classical musicians in the United States and India, respectively, may not possess high social rank after all: Tindall, when, because of her profession, she is dismissed as a trivial nonentity in an upper-crust bar in the Hamptons; ${ }^{22}$ and Miner, when she rejects as incongruous the evidence of the eighteenth-century historical chronicles that it was considered scandalously unfitting to raise professional musicians to the nobility and especially to give them political office. ${ }^{23}$

The key to Merriam's puzzlement lies with his understanding of the word 'status', one that seems to be assumed rather than consciously expressed. It is quite clear from analysing his use of language that status, for Merriam, is primarily commensurate not with relative position in a social hierarchy of roles, jobs, and/or wealth, but with the amount of honour and respect, or, conversely, dishonour and disrespect, ${ }^{24}$ that society accords an individual, group of people, or profession. Moreover, whether an individual is respected or despised is based on society's assessment of whether that person's behaviour is 'respectable' or 'deviant' according to societal standards. ${ }^{25}$ In other words, low status, 'deviant' behaviour, and societal outcasting are the same thing in Merriam's thought. At the same time, it seems that Merriam is also assuming that status - that is to say respect/disrespect - should ordinarily correlate with rank. (Indeed, both Neuman and Cottrell confirm that status is 'ordinarily used' in ethnomusicological literature to mean social rank, although each recognizes the word's ambiguities, especially in Merriam's usage. $)^{26}$ Merriam's conflation of rank and status is made clear only occasionally, for example in his comment concerning Basongye musicians that 'they are often equated with the lukunga, or village messenger, whose status [i.e. occupational/ hereditary rank] is the lowest among the notables'. Also important, however, is his deliberate avoidance of the term 'high respect' in relation to musicians of low status, whose presence in society is tolerated not on the grounds of 'respect', but solely because of their 'high importance' in terms of their function as ritual and social facilitators. Using the example of jazz, he seems to suggest that once a musical style gains the respect of mainstream society, its performers' status may change. ${ }^{27}$ In other words, respect equals high status equals a place among the upper echelons of respectable society.

The assumption that high levels of respect for a person or group customarily demonstrates their high social ranking seems to be something of a 'common sense' view, on the evidence of the social theorists and writers on music cited above. This is particularly so in the case of art

21 Merriam, Anthropology of Music, 133-4.

22 Tindall, Mozart in the Jungle, 225-6.

23 Miner, Sitar and Sarod, 80.

24 Merriam, Anthropology of Music, 134, 136.

25 Merriam, Anthropology of Music, 136.

26 Neuman, Life of Music, 90; Cottrell, Professional Music-Making, 30.

27 Merriam, Anthropology of Music, 136-7. The direction of causation here is not entirely clear. He states that jazz musicians' social location 'is at present in a state of flux', presumably because of the growing respectability - the 'mainstreaming' - of jazz among white upper- and middle-class listeners in the 1960s. 
music, which is considered an elite pursuit and therefore, in Bourdieu's terms, constitutes cultural capital, the possession of which signifies membership of the ruling classes (see below). Levels of respect and honour may customarily have correlated with social rank in the small, supposedly discrete, village societies that were the stereotypical subjects of anthropological fieldwork at the time Merriam was writing, although his low status/high importance formulation in fact constitutes the seeds of a major challenge to this notion. However, one can easily find numerous examples in more stratified societies where a high degree of respect or honour for someone's talent in a particularly specialized area, or even a significant level of remuneration, is not commensurate with high social position in a culturally accepted system of social ranking by birth, role, and/or occupation - think, for instance, of the snobbish nuances of the term 'nouveau riche'. There is no doubt that the footballer David Beckham, for example, is greatly respected for his abilities on the football pitch, and is highly paid for his extraordinary talents. This does not change the fact that he remains steadfastly working class, and that because he works with his body, not his brain, in a profession that is primarily considered entertainment and therefore not directly 'useful' to society, he is unlikely ever to be taken seriously as a candidate for Prime Minister or chief executive. ${ }^{28}$ Respect is clearly not identical with rank.

The confusion of respect with rank explains both Merriam's initial puzzlement and the perplexity of some social theorists and writers on music when confronted with evidence that the occupation of 'musician' may be accorded low respect, but the abilities of musicians may at the same time be awarded high respect. I say 'some' theorists and writers because the way I have presented Merriam here is not the one in which interpreters have usually understood his tripartite formulation of low status/high importance/tolerance of 'deviance'. Because of Merriam's focus on 'deviance', or on outsider status, some scholars have applied his formulation only to the surprisingly large number of societies that delegate the important role of musician within mainstream society to foreigners, minorities, or members of socially outcasted or 'deviant' groups, communities usually excluded from participation in mainstream society. ${ }^{29}$ Other scholars have instead taken 'low status' to mean, primarily, low occupational/class rank, and 'importance' to include attributions of respect, ${ }^{30}$ a position very close to what I shall argue is the base position for professional musicians in most, if not all, societies.

28 I am indebted to Stephen Cottrell (personal communication 2006) for a further example from the world of football: that of George Weah, World Footballer of the Year 1995, who in 2005 was narrowly defeated in the election for President of Liberia. Born in a slum, he became an international celebrity through his sporting talents. According to the BBC, 'he was counting on his status as the world's most famous Liberian to win the polls', but was defeated owing to the impression that he 'lacked experience' - 'as a politician he is a novice - a babe-in-the-woods' - and the less charitable dismissal of him by the Liberian elite as a 'high-school drop-out'. See 'Profile: George Weah', BBC website, 11 November 2005, <http://news.bbc.co.uk/1/hi/world/africa/4403120.stm> (accessed 1 November 2006).

29 B. Nettl, Study of Ethnomusicology, 342.

30 For example, Cottrell, Professional Music-Making, 193-4, 126-7. He argues that 'Merriam's paradigm does indeed hold true for musicians in an urban Western context', but with the important exception that a 'fortunate few' are able to attain high social rank (as evidenced by knighthoods and baronetcies) solely through their musical endeavours; in other words, music may be a means for some of permanent social elevation. In this paper I shall argue that, unlike Merriam's formulation, the paradigm of liminality easily accounts for such anomalies. 
It is certainly possible to extrapolate this second interpretation from Merriam, because his formulation resonates so powerfully with the evidence in many societies concerning the location of musicians who are not ordinarily considered marginal or 'deviant', such as European art musicians, or pop stars like (pre-marriage) Britney Spears who are marketed as 'wholesome'. However, this is not what Merriam was describing. Indeed, because of his ambiguous use of the word 'status', both interpretations involve fundamental problems that make Merriam's formulation less than useful in determining the social location of musicians. If one takes 'status' to mean 'respect/disrespect', as I have argued Merriam does, the third part of his formulation is redundant, because societal tolerance of 'deviance' is merely the necessary solution to the social conundrum of having to bring marginal or 'deviant' musicians into the centre of social life on occasion because of their importance to ritual or to social cohesion. Merriam's formulation in this interpretation can therefore apply only to musicians who are already stigmatized as 'deviant' - one might think of the traditional stigmatization of Roma in this respect ${ }^{31}$ - and says nothing at all about rank. If, on the other hand, one takes 'status' to mean 'rank', societies in which musicians conform to the standards of 'respectable' society and are visibly awarded respect should be considered of high rank. Indeed, Cottrell notes that the rank of professional musician in London remains ambiguous if one analyses musicians' location in Merriam's terms, because while musicians may consider themselves to be 'not highly regarded at all', neither can they be at the bottom of the heap, since they are not considered to be particularly 'deviant'. ${ }^{32}$ Merriam's puzzlement and the continuing perplexity of other writers over the significance of respect in all this indicate that neither interpretation is fully satisfactory.

\section{A Possible Solution to the Puzzle: Institutionally Liminal Status}

I do not wish to dismiss the explanatory potential of Merriam's formulation in relation to the link between rank and culture; indeed, my discussion here is indebted to his. However, I want to turn instead to two other, less often cited statements of Merriam that point us towards what I consider to be a more complete understanding of the social location of musicians, one that makes sense of the relationship between respect and rank, as well as the uncertainty and ambiguity scholars express concerning musicians' location, and also the ability of a few great stars to transcend their location and climb to the higher strata of their societies. The first statement is Merriam's insight that the Basongye consider musicians to possess the status of servants - 'people who can be ordered about; they work for other people and not for themselves'. ${ }^{33}$ The second, arrived at to make some sense of his puzzlement over the issue of high respect, is that some musicians, instead of high rank, may 'retain [. . . ] rather what might be called respect of a limited tangible nature on the part of the people for whom they sing or play'. ${ }^{34}$ In this paper I shall argue that respect alone, taken apart from other considerations,

31 See Hooker's essay in this issue.

32 Cottrell, Professional Music-Making, 194.

33 Merriam, Anthropology of Music, 136.

34 Merriam, Anthropology of Music, 133 (my emphasis). 
is not an indicator of social rank in relation to musicians. Rather, all professional musicians, including classical musicians, regardless of whether or not their behaviour is considered 'deviant' or 'respectable', are of lower social rank relative to their patrons because they occupy a service profession. From the patron's perspective, listening to music is entirely for his or her own benefit, not the musician's; and - sidestepping questions of aesthetics and enjoyment - music's primary social function à la Bourdieu is to increase the patron's cultural capital. ${ }^{35}$ However, the patron's limited tangible respect for the musician's art - a respect that largely serves to demonstrate the patron's cultural competence as a bona fide member of the ruling classes - nonetheless enables the musician temporarily, and sometimes permanently, to cross social boundaries ordinarily closed to members of his or her community, granting the professional musician institutionally liminal status. I maintain that it is through a consideration of musicians in the context of liminality, following on from Victor Turner's work, that we come to a much closer understanding of the social location of musicians in modern societies.

\section{Victor Turner, Liminality, and Working in the Stairwell}

The word 'liminal' comes from the Latin limen, meaning 'threshold', and 'liminality' refers to those times and places, ritually marked out as special and usually temporary, during which thresholds or boundaries of some kind are crossed, most notably in rites of passage such as births and marriages, or in cyclical events like Mardi Gras that involve the ludic inversion of social norms. ${ }^{36}$ Other words have been used to describe liminal times and places - the 'betwixt and between', 'neither here nor there', 'limbo', ${ }^{37}$ 'transition', ${ }^{38}$ and, borrowing from Homi Bhabha, the 'hither and thither', the 'in-between', the 'interstices'. Using the evocative image of the stairwell between two floors, Bhabha notes that 'the hither and thither of the stairwell [...] prevents identities at either end of it from settling into primordial polarities[; it is an] interstitial passage between fixed identifications'. ${ }^{39}$ Liminality is therefore a state of ambiguity; it is what it means to move or to sit on the stairs between worlds. Ethnomusicologists have often employed Turner's application of liminality to ritual events such as Carnival, and more recently Cottrell has applied it to the 'ritual' of the Western orchestral concert. ${ }^{40}$ But to my knowledge it has rarely been applied generically to an analysis of musicians' social location, although it has been applied to gender boundaries. ${ }^{41}$ Such an application is, however, fully consistent with Turner's ideas, because he also uses liminality to describe the condition of people who cross thresholds. He further notes that in societies that

35 Bourdieu, Distinction, 7.

36 Van Gennep, Rites of Passage, 10-11, 21; Turner, Anthropology of Performance, 102.

37 Turner, Ritual Process, 95, 97.

38 Van Gennep, Rites of Passage, 10-11.

39 Bhabha, Location of Culture, 2-5.

40 Cottrell, Professional Music-Making, ch. 7; see also his essay in this issue.

41 See particularly Koskoff, Introduction to Women and Music, 11-12, and other contributions to that volume. See also the work of van Nieuwkerk, 'A Trade Like Any Other' (website); Andrea Deagon, 'Dancing at the Edge' (website); and Cottrell, Professional Music-Making, 143; cf. Turner, Ritual Process, 109-10. 
have developed highly complex divisions of labour, liminality has become permanently institutionalized in certain professions, notably the priesthood and religious orders. ${ }^{42}$ In this paper I aim to show that permanent, institutionalized liminality is also applicable to professional musicians. Before doing so, I shall delimit more precisely the aspects of Turner's work that define my deployment of the term, because liminality has lately become something of a trendy concept, and in certain usages has become stretched almost to the point of meaninglessness.

Turner derives the concept of liminality from the 1909 work of van Gennep on rites of passage - initiation ceremonies, weddings, births, and so on. Making an analogy with territorial border crossings, van Gennep notes that all such rites involve the crossing of a threshold from one world to another, and that rituals involving doorways and thresholds form important parts of rites of passage in many cultures. He divides rites of passage into three phases: rites of separation, in which the passenger is separated from the normal flow of life; transition rites, which surround the crossing of the threshold from the state left behind to the state yet to come; and rites of incorporation, in which the passenger re-enters the ordinary flow of life, having permanently entered into a new state. It is the transitional phase, which may be 'sufficiently elaborated to constitute an independent state', that van Gennep labels a liminal or threshold state and in which Turner and I are interested. ${ }^{43}$

Noting that the characteristic features of the liminal phase of rites of passage are also typical of other events culturally marked off as 'special', Turner extends the concept of liminality first to other kinds of ritual, and later to performance genres, particularly theatre. Liminality to Turner is not simply the act of crossing or straddling a boundary or threshold. Rather, the liminal space, phase, or condition is one of temporary ambiguity, fluidity, and statuslessness, defined by the brief lifting of normal social rules, and, more significantly, the momentary levelling of social ranks and statuses and the reversal of high-low power relations through ritual and/or play. Most importantly for our purposes, Turner defines two separate types of ritual involving a liminal phase: rituals of status elevation, and rituals of status reversal. Both involve the temporary disappearance of 'secular distinctions of rank and status' as the participants go through what he calls a 'limbo of statuslessness'. The first type pertains primarily to rites of passage in van Gennep's original conception: the permanent passage of individuals from a lower to a higher life stage. Rituals of status reversal, on the other hand, are usually associated with cyclical or calendrical ritual, involve no permanent change of state for the participants, and involve the temporary and often parodic or comical elevation of people 'who habitually occupy low status positions in the social structure [who are] positively enjoined to exercise ritual authority over their superiors; and they, in their turn, must accept with good will their ritual degradation'. ${ }^{44}$ It is in Turner's descriptions of rituals of status reversal that we find many points of contact with the idea that musicians may

42 Turner, Ritual Process, 106.

43 Van Gennep, Rites of Passage, 11, 21. Turner, however, uses the term 'phase' in preference to 'state', because he considers liminality to be temporary and a 'state' to be 'any type of stable or recurrent condition that is culturally recognized', with the liminal phase being the period/place between them (Ritual Process, 94).

Turner, Ritual Process, 167, 95, 97. 
be an institutionally liminal class. I shall outline these and then make the connection with my work on North Indian classical musicians in the later Mughal period (c. 1658-1858), from which my hypothesis derives.

Turner already goes some way to suggesting that musical performance may be a liminal event when he notes that: 'Most cultural performances belong to culture's "subjunctive" mood [...] that mood of a verb used to express supposition, desire, hypothesis, possibility, etc., rather than to state an actual fact [. . . ] ritual, carnival, festival, theatre, film, and similar performative genres clearly possess many of these attributes. ${ }^{35}$ Indeed, music in most societies is commonly present at both ritual and 'pure' entertainment events, further suggesting the connection between the two that Cottrell explicitly makes in relation to Western classical music concerts; this is not a new idea. During rituals of status reversal, Turner argues that:

Everything is switched into the subjunctive mood for a privileged period of time - the time, for example, of Mardi Gras [...] Public liminality is governed by public subjunctivity. For a while almost anything goes: taboos are lifted, fantasies are enacted [.. .] the low are exalted and the mighty abased [.. .] Ambiguity reigns [...] the vices, follies, stupidities, and abuses of contemporary holders of high political, economic, or religious status may be satirized, ridiculed, or contemned $[$ sic] in terms of axiomatic values, or these figures may be rebuked for gross failures in commonsense.

This subjunctivity, this mood of uncertainty and possibility that is characteristic of the liminal phase or condition thus provides a 'frame' for society to explore its 'deepest values' and test its normative rules and structures, in part through challenging and contesting them. The liminal moment is a moment of anti-structure, during which a space is created for the reversal and ludic renegotiation of social rank and status norms, in a cultural and aesthetic arena, through ritual and performative means. Turner calls this momentary social levelling and temporary utopian feeling of social oneness, this underlining of deeply held humanitarian values, 'communitas'. It is not entirely incidental here that Turner considers music to be a particularly apt medium for conveying 'the quality of spontaneous human communitas'. ${ }^{46}$

Turner also makes the important point that the subjunctivity of the liminal phase is nonetheless limited and patrolled, so that the social order is never really disturbed. He notes that the possessors of political and social power always surround liminal phases and conditions with 'prescriptions, prohibitions, and conditions', because, from the point of view of 'those concerned with the maintenance of "structure", all sustained manifestations of communitas [...] appear as dangerous and anarchical' in that they invert 'structure'. The play is dangerous because it negotiates social boundaries; but it is simultaneously crucial to

45 Turner, Ritual Process, 101. Strictly speaking, Turner does not consider performative genres to be liminal in the same way as ritual, coining another word 'liminoid', or 'liminal-like', to describe the deferred or 'at a distance' play with status, roles, and taboos that occurs, for example, on the theatrical stage. This distinction is not present in his earlier output, and, I would suggest, is unnecessary. This is particularly so in relation to the social liminality of musicians, who, unlike actors, in many societies take part in both ritual and 'purely' performance events.

Turner, Ritual Process, 102, 107, 110, 164. 
the smooth functioning of society for the same reason. If kept under control, rituals of status reversal act to reinforce normative power relations by making plain 'social categories and forms of grouping that are considered to be axiomatic and unchanging [...] Cognitively, nothing underlines regularity so well as absurdity or paradox. Emotionally, nothing satisfies as much as extravagant or temporarily permitted illicit behavior. By making the low high and the high low, [rituals of status reversal] reaffirm the hierarchical principle.' ${ }^{7}$

Thus my first point of contact has to do with the reversal or levelling of status norms and power structures that occurs in the liminal moment of any cultural performance, in a shared search for individual and communal satisfaction. My second concerns the temporary and largely illusory nature of this reversal, because it is always permitted by the powerful, is conducted using their ground rules, and acts to contain and dispel any real attempts by those of lower rank or status to climb the social ladder.

Most centrally, my third point of contact has to do with the nature and role of the people of low status or rank who come face to face with their structural superiors in these rituals of status reversal, and, in the liminal moment, exert power over them. Turner states that in [such rituals] the group or category that is permitted to act as if it were structurally superior [...] is, in fact, perpetually of a lower status' (my emphasis). He further notes that 'communitas bearers' - those who playfully enact the role of society's conscience in such encounters - invariably belong either to institutionally liminal groups, marginal groups, or 'occupy [society's] lowest rungs'. In other words, they are all 'structurally inferior'. Turner then draws attention to particular categories of people that societies seem to set aside specifically for this role - " "holy beggars", "third sons", "little tailors", and "simpletons", who strip off the pretensions of holders of high rank and office and reduce them to the level of common humanity and mortality'. ${ }^{48}$ Although he does not explicitly say that such people are liminal, those who are institutionally permitted to enter elite spaces undoubtedly are, because they cross and recross the boundaries of social rank that are critical to the notion of liminality. The institutionally liminal figure usually named here is the court jester. ${ }^{49}$ Turner notes that court jesters in Europe were 'usually men of low class [...] who [had] clearly moved out of their usual estate [.. . ] In a system where it was difficult for others to rebuke the head of a political unit, we might have here an institutionalized joker, operating at the highest point of the unit [...] a joker able to express feelings of outraged morality. ${ }^{50}$

In other societies musicians and dancers took the role of court jester. In North India this role was played until recent times by communities of musical entertainers and satirists, like the bhands and bhavaiya, who were talented singers and musicians and expert mimics. ${ }^{51}$ Despite the fact that their low social rank was explicitly noted, seventeenth-century books of

47 Turner, Ritual Process, 102, 109, 176.

48 Turner, Ritual Process, 176, 125, 110.

49 See, for example, Cottrell, Professional Music-Making, 143-4; Blok, in van Nieuwkerk, 'A Trade Like No Other'.

50 Turner, Ritual Process, 109-10.

51 See, for example, remarkably similar descriptions of bhands, bhavaiya, and naqqals in the sixteenth-century Ain- $i$ Akbari by Abul Fazl; in the early twentieth-century British census reports of Ibbetson (Panjab Castes, 237) and Crooke (Tribes and Castes, vol. 1, p. 256); and Emigh and Emigh's ethnographic account (1996) of a modern-day bhand, 'A Joker in the Deck: Hajari Bhand of Rajasthan'. 
princely etiquette instructed Mughal noblemen to employ and to enjoy the performances of bhavaiya, 'who realistically satirize all sorts of people. If one wants to learn about one's own faults, one should once in a while sit in one's own ambush'. ${ }^{22}$ Although the bhands, in contrast, were frowned upon in the seventeenth century as unsuitable for patronage because their dancing was considered sexually enticing and because they were largely entertainers for the lower classes, ${ }^{53}$ in the eighteenth century the bhands nonetheless became the pre-eminent jesters at the imperial and regional courts, with several contemporary stories of the emperor Muhammad Shah (reigned 1719-48) submitting delightedly to their musical mockery. ${ }^{54}$

\section{The Attributes of Liminal Personae}

In summary, in attempting to identify institutionally liminal personae, there are several attributes one would expect a member of an institutionally liminal profession to possess. The first is structural inferiority, that is to say, either originally coming from or joining a group designated by the 'respectable' majority as low-rank, marginal, outsider, or otherwise stigmatized. The first attribute, however, may be disguised by the second attribute, ambiguity of status, because, as Turner notes, 'the attributes of [.. . ] liminal personae ('threshold people') are necessarily ambiguous, since [...] these persons elude or slip through the network of classifications that normally locate states and positions' ${ }^{55}$ Thirdly, one would expect liminal personae to take on the properties of the liminal state on a permanent basis, or at least when carrying out their duties. In the case of liminal groups that embody the attributes of rituals of status reversal, these should include some or all of the following: (1) the subversion of society's norms and rules, (2) sanction to speak truth to power, (3) the temporary exertion of power over the powerful, and, as Turner notes when describing 'the liminality [...] of poverty', (4) 'ostentation and pseudohierarchy'. ${ }^{56}$ One would also expect these structural inferiors to be (5) bearers of communitas.

In passing, I should note that liminality is not the same thing as marginality, contrary to much scholarship following Homi Bhabha, although the confusion of terms is already partly present in van Gennep's work, and occasionally in Turner's, even if he clarifies several times that they are not the same in his thinking. ${ }^{57}$ Bhabha, in seeking the location of culture, often collapses almost everything into liminal time and space. And in part he has a point. First, with regard to time, he argues that the undermining of and play with fixed binarisms characteristic of postmodern and postcolonial literature are symptomatic of the fact that we are living in an uncertain, 'post', and therefore liminal, age between modernity and a future not yet known. ${ }^{58}$ Secondly, his idea that the geographical and ideational space of the entire postcolonial nation is liminal is an attractive one; in other words, that the legitimate presence of outsiders within

52 Ahmad, 'The British Museum Mirzanama', 101.

53 Ahmad, 'The British Museum Mirzanama', 101.

54 Dargah Quli Khan, Muraqqa'-i Dehli, 97; Sharar, Lucknow, 141.

55 Turner, Ritual Process, 95.

56 Turner, Ritual Process, 107, 200.

57 Turner, Ritual Process, 125.

58 Bhabha, Location of Culture, 1-2. 
the nation in the form of ethnic minorities undermines the idea of 'the people', the 'national self', as homogeneous, leading to a constant, fluid, back-and-forth play with the boundaries of national and individual identity. ${ }^{59}$ However, making all contemporary time and space liminal has the effect of emptying liminality entirely of its explanatory power. Moreover, given that Bhabha identifies the 'other' in this playful equation as 'margins and minorities', it is unsurprising that his followers (including many music scholars) have identified liminality with marginality and minorities. When one finally encounters oxymorons like liminal boundaries' in Bhabha's work (boundary-crossing boundaries?), ${ }^{60}$ it is hard not to conclude that he is merely using 'liminal' as a synonym for 'vague', thus seriously reducing its specificity as a concept.

As Turner makes clear, there often is a connection between marginality and liminality, in that marginal people can and frequently do become liminal during rituals of status reversal, ${ }^{61}$ or by taking up an institutionally liminal profession. Nonetheless, the difference between the two is simple. Marginality - to be marginalized - implies restriction, a lack of ability, or permission denied, to cross boundaries. Liminality, by contrast, implies freedom or permission to cross boundaries, an active ability to do so. In discussing the social liminality of musicians, therefore, I am describing liminality actively, as an ability - the ability to cross boundaries, or to live permanently between two worlds.

That Turner indeed considers musicians as belonging to the category of what he calls 'liminars' - or institutionally liminal groups - is finally suggested when he notes that 'Prophets and artists tend to be liminal [...] people, "edgemen" '.62 Because he regards music as almost unique in its capacity both to symbolize and to bring about 'spontaneous human communitas', in one passage (never, to my knowledge, previously commented upon by music scholars) he names musicians as institutionally liminal beings, taking as his examples Bob Dylan and the Bauls of Bengal:

A fascinating example of the convergence, under modern conditions of transportation and communication, of Western and Eastern liminars and communitasbearers may be found in many music shops today. The cover of a recent recording of Bob Dylan's songs shows the American folk singer and spokesman of the structurally inferior flanked by Bauls, these musical vagabonds of Bengal: guitar and ektara have come together. It is even more fascinating to consider how often expressions of communitas are culturally linked with simple wind [...] and stringed instruments. ${ }^{63}$

Other writers have also suggested on occasion that professional musicians may belong to a liminal occupational category. Blok, for example, includes musicians, singers, and dancers among his list of 'dishonourable' professions in fourteenth-century Germany, professions

\footnotetext{
59 Bhabha, Location of Culture, 212-16; see also Hooker in this issue.

60 Bhabha, Location of Culture, 213.

61 See also Bywater in this issue.

62 Turner, Ritual Process, 128.

63 Turner, Ritual Process, 164.
} 
designated 'dishonourable' because they all 'in one way or another [...] are involved with margins, thresholds, and boundaries - bridging the differences between clear-cut categories like self and notself, city and countryside, man and animal, culture and nature' ${ }^{64}$ Andrea Deagon, too, notes the connection between the liminality of professional Egyptian belly dancers and their social stigmatization: in a gender-segregated society they are women who perform for unrelated men and who disobey the sartorial norms of feminine modesty; and who are allowed to do so only on the grounds that they come from lower classes of society than their patrons, ${ }^{65}$ who would never allow their own women - often equally talented dancers - to perform outside the family setting. ${ }^{66}$ The sense of dwelling permanently between two worlds is also revealed by occasional comments that musicians let drop in interviews and biographies. The quotation that stands at the head of this article comes from the 1966 autobiography of Lena Horne. Throughout she recounts what can only be described as her lived experience of institutional liminality as a black woman performing largely for white audiences: 'rootless in the world - a stranger in the white world [...] a stranger in the [black] world'. This undoubtedly glorious transitoriness ${ }^{67}$ was made possible solely by her profession as a musician. ${ }^{6}$

\section{The Social Liminality of Musicians in the Mughal World}

In the remainder of this paper I shall explore in greater depth the evidence that professional musicians belong to this category of institutionally liminal professions, initially basing my argument on my work on the seventeenth- and eighteenth-century North Indian mehfil-the intimate gathering of connoisseurs and musicians in exclusive elite spaces for the purpose of musical performance. The connection with twentieth-century North India is not as tenuous as it might appear, because the mehfil in its Mughal form, self-consciously retaining cultural links (imagined or real) with the Mughal past, remained the forum par excellence for the performance of North Indian classical music until at least Independence in $1947 .{ }^{69}$ Indeed, nostalgic renderings of the mehfil endure almost to the present day in musicians' memories and in famous films like Jalsaghar and Umrao Jaan, as well as in modern attempts to recreate the atmosphere of the mehfil in the public concert hall. ${ }^{70}$ Following this section I shall return to the twentieth century and to other societies to demonstrate the more widespread applicability of social liminality to musicians. I should note at the outset that I first read Victor Turner's work on liminality only very recently, long after I had developed my own ideas concerning the liminality of musicians in the Mughal empire. The connections are striking.

64 In van Nieuwkerk, 'A Trade Like Any Other'.

65 Deagon, 'Dancing at the Edge'.

66 Van Nieuwkerk, 'A Trade Like Any Other'.

67 In terms of her wealth, fame, and public acclamation; see Horne and Schickel, Lena.

68 Horne and Schickel, Lena, 3; cf. Becker, Outsiders, 99.

69 For detailed historical and ethnographic accounts of twentieth-century mehfils and their etiquette see Qureshi, 'The Indian Sarangi', and Silver, 'Adab of Musicians'.

70 See Neuman, Life of Music, 71, 219; and Silver, 'Adab of Musicians', 319-21. For a very similar narrative to the one I unfold here, but for the twentieth century, see Qureshi, 'Confronting the Social'. 
My interest in liminality as an explanatory frame for relations between professional musicians and their audiences stems from my work on North Indian classical musicians, gender, and social class in the Mughal empire. The Mughals were a Central Asian Muslim dynasty who ruled over North India from 1526 until 1858, when the last Mughal emperor was deposed by the British Crown for his role in the Indian Uprising of 1857. The ultimate arbiters of musical taste and fashion in this period were the Mughal emperors and, more importantly after $1668,{ }^{71}$ the noblemen, known as mirzas or princes, who are easily identifiable in the records by the finely stratified and highly bureaucratic hierarchical system the Mughal emperors used to rank the upper echelons of male society. ${ }^{72}$ Because changes in the taste of patrons inevitably affect which musicians and musical styles are deemed worthy of patronage, I wished to investigate the reasons behind, and the restrictions on, the patronage of music in this Muslim male elite milieu, given that music is at best controversial in Muslim societies. Conversely, it became evident that a study of musical patronage among the male elite shed a great deal of light on gender and class relations in the empire generally, for reasons that had to do with the peculiar liminality of musicians as an occupational class. ${ }^{73}$

Mughal society in seventeenth-century North India was sharply segregated first by gender, with elite women confined to the private domestic space of the haram, and secondly by class stratification, with elite and socially aspirant men in public male spaces required by the explicit proscriptions of etiquette to shun familiarity with all men of lower rank. This applied both to servants and to any person who was of considerably lower rank than oneself. It was mandated in the books of princely etiquette known as mirzanama literature, in statements such as '[The prince] should not allow a mean person to be his companion; he should not [even] look at such a person if he stands in front of him [. . . ] he should not speak to a person of low or mean origin without necessity; and he should try to communicate with him [only] by signs or gesture'. ${ }^{74}$ Both gender and social-rank distinctions were physically manifested in the architecture of Mughal urban spaces. The spaces in which one was ordinarily permitted to appear, and one's physical proximity in those spaces to the most powerful person present, publicly made visible one's social rank (see Figures 1 and 2). ${ }^{75}$

The known presence of musicians in the most elite male spaces, attested in both written descriptions and miniature paintings, would seem to suggest, on first appearances, that they possessed high social rank. The veneration that patrons awarded musicians for their art is certainly undisputed, with panegyric statements about musicians commonplace in the literature, ${ }^{76}$ and Aurangzeb's bestowal of 7000 rupees on Khushhal Khan in 1663 for a single performance not out of the ordinary. ${ }^{77}$ Music historians have usually taken the high regard in

71 The date when the emperor Aurangzeb renounced his patronage of music for personal religious reasons; see Brown, 'Did Aurangzeb Ban Music?'.

72 See Brown, 'Hindustani Music', 39, 53.

73 For more extensive details see Brown, 'Hindustani Music', 118-76.

74 Ahmad, 'The British Museum Mirzanama', 106.

75 See also Brown, 'Hindustani Music', 119-23.

76 For example, Khan Rasikh, Risala-i Zikr-i Mughanniyan-i Hindustan, 30-1.

77 Khafi Khan, Muntakhab al-Lubab, 175. 


\section{Haram (Women's Quarters)}

(the emperor, women, the women's close male relatives)

\section{Hall of Special Audience}

(the emperor, high officials, entry on emperor's invitation only)

Entrance Courtyard outside

the wall

common

people

the

\section{naqqara-khana (drum house)}

(symbol of emperor's presence)

Figure 1 The central enclosure of the Mughal imperial camp, c. 1593, showing the division of space by gender and social rank in the emperor's tents. (Abul Fazl, Ain-i Akbari, 336)

which their upper-class patrons undoubtedly held hereditary musicians as proof that classical musicians were traditionally of comparatively high social rank in North India. On the contrary, classical musicians' low rank was equally clearly stated in contemporary writings. The Persian, Hindi, and Urdu literatures that constitute the Indian ruling elites' own records of their histories establish unequivocally that from the sixteenth until at least the early twentieth centuries the Indian elites considered all professional musicians to be 'low-born'. ${ }^{78}$ Where their caste can be established, they were also of low caste. The two most numerous communities of hereditary professional musicians were the kalawants and the dhadhis, who later became known as mirasis. Technically speaking, these are occupational titles rather than caste names, kalawant simply meaning 'artist' and dhadhi 'drummer', although by the seventeenth century at least they functioned as castes. Indeed, the name dhadhi is known to have been an alternative name for the 'exceedingly low' dom caste. ${ }^{79}$ A perceived connection, 


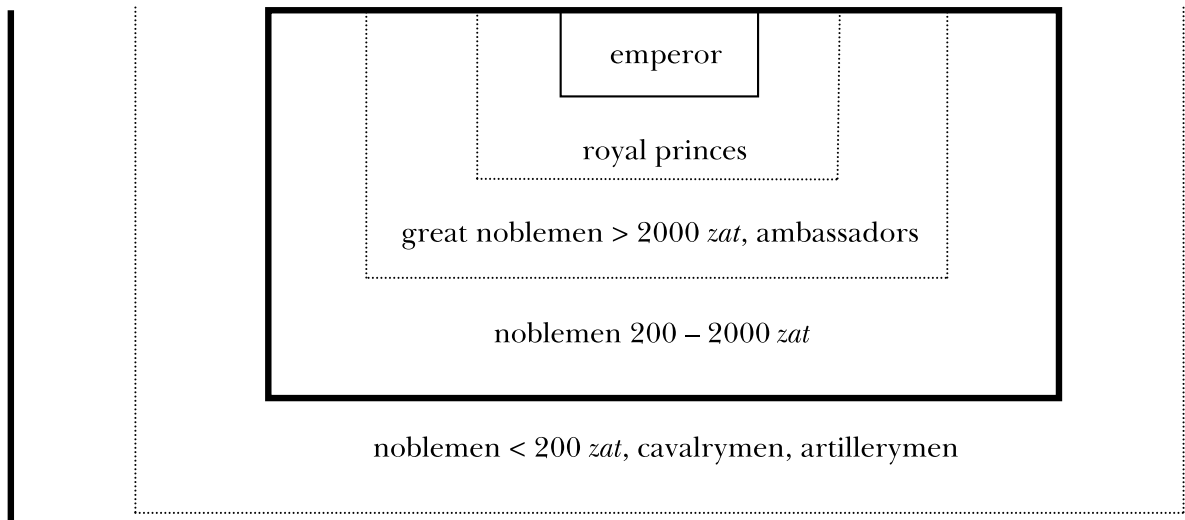

footsoldiers, servants

naqqara-khana

Figure 2 The Hall of Common Audience, Shahjahanabad (Red Fort, Delhi), showing the fine differentiations of rank manifested in its physical divisions; musicians were generally seated in the great noblemen's enclosure; zat was the nominal unit of rank; the naqqara-khana ('drum house') was the balcony above the entrance gate to the fort where the military band, aural symbol of the emperor's presence, played. (Blake, Shahjahanabad, 91; Wade, Imaging Sound, 4)

correctly or falsely, between musicians and sexual service is also ever present as a shadow until at least the mid-twentieth century beneath the more hagiographic rhetoric about the glories of Indian musicians..$^{80}$

These musicians are traceably the ancestors of some of today's hereditary classical musicians. At the turn of the twentieth century the British census takers classified all communities of classical musicians, including the dhadhis and mirasis, as low caste or outcast, and stigmatized several communities as pimps and prostitutes. Because of the racism underpinning the often faulty taxonomies of the British colonial administrators, and because modern Indian biographies of musicians tend towards the hagiographical, there has been considerable scholarly reluctance to accept this classification of musicians as of low rank and caste, on any level. However, the census takers included several Hindi proverbs that proved their point about the poor view of musicians expressed by at least some segments of Indian society, such as 'Taking presents is the way of pimps and buffoons [doms and dhadhis]; true love is quite a different thing' ${ }^{81}$ Bakhle has also demonstrated that the renowned classical musicians at the court of Sayajirao III of Baroda (d. 1939) were treated no better than the servants they in fact were, roughly equivalent in rank to wrestlers, despite later biographers' romantic inflation of their importance to the Maharaja. ${ }^{82}$ That musicians were widely perceived to be of low rank

80 For example, see Brown, 'If Music Be the Food of Love', 63-5; Magriel, 'The Sarangi in North Indian Music'.

81 Crooke, Tribes and Castes, vol. 1, p. 277.

82 Bakhle, Two Men and Music, 27-33. 
is the obvious explanation for the Indian middle classes' well-documented status-conscious aversion to hereditary classical musicians at the beginning of the twentieth century, given that the evidence of earlier periods is incontrovertible on this point. In saying this, I do not wish in any way to denigrate any community regarded by their society as 'low', especially not Hindustani musicians. But to overlook the historical existence of class-based divisions between performer and patron in North India is to deny past instances of injustice and oppression against these communities. It is also to overlook methods of resistance that certain lower-class men and women were able to employ against the ruling classes by virtue of their possession of something of great value to the elite.

To return to the seventeenth century: the presence of low-rank musicians in the most elite spaces thus constituted a tangible paradox. Almost uniquely in a society so visibly stratified, the performance of music and dance enabled not only male but also female performers of low social rank to cross the ordinarily impenetrable boundaries of rank and gender segregating them from the elite and, in the case of women, from male space. The only reason that these particular representatives of the lower strata of society were permitted to enter elite male space was the high cultural value and social importance that the elite attached to music. By the mid-seventeenth century the patronage of classical music had become central to the notion of what it meant to be a mirza or nobleman. This is demonstrated by the appearance in the mirzanama literature and in musical treatises of copious detailed rules for the conduct of the mehfil. This prescriptive literature reveals two reasons why the male elite patronized music in the Mughal empire, one of them explicitly stated, the other more inherent in the nature and purpose of the literature itself, but nonetheless exceedingly important.

The explicitly stated purpose of listening to music was simple: to arouse and satisfy the emotions, or, as the seventeenth-century nobleman and music theorist Faqirullah put it, to 'charm the listener'. ${ }^{83}$ A major duty of the musician's etiquette, according to another noble theorist, Mirza Khan, was 'to arouse in performance pleasure and complete enjoyment in one's listeners' ${ }^{84}$ The emotional power of music also had other, more legitimate benefits in the Mughal world, namely, medicinal and spiritual benefits. ${ }^{85}$ However, in the courtly mehfil, where the purposes emphasized were primarily aesthetic and emotional, the required emotional effect could be realized only if the musician achieved perfection in his or her performance of the raga, the modal and melodic basis of all Indian classical improvisation. ${ }^{86}$ The musicians and patrons were charged to work together, fulfilling their complementary roles in order to achieve this moment of emotional release and temporary oneness, a state that is highly reminiscent of Turner's idea of communitas. ${ }^{87}$ But interestingly, it was the patron's duty to ensure that this happened; to do so required that he possess the knowledge of a connoisseur; and this principle of knowledge ties into the other, less explicit reason why the patronage of music was so important to the Mughal princes. The prescriptive literature

83 Faqirullah, Rag Darpan, 75.

84 Mirza Khan, Tohfat al-Hind, f. 109b-10a.

85 See Brown, 'Hindustani Music', 55-7, 138-41.

86 Faqirullah, Rag Darpan, 79, 81; Mirza Khan, Tohfat al-Hind, f. 114b.

87 See also Qureshi, 'Confronting the Social', 30-2. 
mandates knowledge as the primary duty of the nobleman ${ }^{88}$ in part for the reasons just cited, but primarily in order to prove to his peers, who were his social judges, his mastery of elite male etiquette.

The required knowledge of the art of music included music theory - knowledge of style and what constituted beautiful execution, knowledge of the theory and practice of raga, appreciation of the lyrics of compositions, and an understanding of musical and affective meaning - as well as the practical art of singing and knowledge of the correct procedure for the mehfil. ${ }^{89}$ Knowledge of the art of music was a great accomplishment in its own right. ${ }^{90}$ However, its primary stated purpose was to enable the mirza publicly to display his cultural competence, and therefore his high social rank, in the following ways. Knowledge helped the mirza to discern which individual musicians, which types of musician, and which genres were worthy of his patronage, and those that were not, and thereby to discern which of his peers were of high enough status to be worthy of his companionship. Should the mirza sing for his companions - a risky undertaking in any case for the maintenance of his prestige - his knowledge would enable him to avoid the embarrassment of disgusting his listeners. ${ }^{91}$ And knowledge enabled the mirza to correct any faux pas his musicians might make in front of his guests. ${ }^{92}$ Similarly, any genres that were slightly unorthodox, even if they were 'perfect works of art', should not be patronized, because they were invariably performed badly ${ }^{93}$ and this would reflect badly on the patron.

The knowledge on which these judgements were based was directed by a single principle: that the patron's choice of music directly reflected his position in the social hierarchy. Which musicians and genres should be patronized was determined by their putative 'natural' audience in society at large. Only the best performers of the most serious art music genres should be patronized by the mirza; inadequate performers, and musician communities who were customarily patronized by women or the lower classes were to be kept out of the princely mehfil. ${ }^{44}$ This created an internal social hierarchy or pseudohierarchy of musicians from high to low prestige which mimicked the external social hierarchy, because it was based on the social rank of their audiences, but which had no impact on the musicians' low social rank in society at large. Musicians associated with the haram or the bazaar were excluded from the princely mehfil, not because they were of lower social rank than the top performers, but because, by association, they would make the patron look like an arriviste, effeminate, or lower class, exposing him as a fraud. The main purpose of knowledge, therefore, was to protect the patron from being shown up in front of his peers as 'ignorant and undignified', and thus as a false and unworthy mirza. Conversely, patronizing the 'right' music acted as proof of the patron's high social rank.

88 Faqirullah, Rag Darpan, 165.

89 Ahmad, 'The British Museum Mirzanama', 101.

90 Kamran, 'The Mirzanamah', 3.

91 Ahmad, 'The British Museum Mirzanama', 101.

92 Hasan, Sarud al-Bahr, f. 3b.

93 Ahmad, 'The British Museum Mirzanama', 101.

94 See Brown, 'If Music Be the Food of Love', 75-6. 
The idea that patronizing the 'right' music publicly indicated high social rank fits in precisely with Bourdieu's notion of cultural capital, namely, the knowledge of the tastes and habits of the ruling classes required to wield cultural products 'as a resource of [social] power' ${ }^{95}$ That classical music constituted cultural capital for the Mughal patron is, I think, undisputed. That it constituted cultural capital for the musician, however, is more questionable, because the possession of cultural capital and membership in the ruling classes is the same thing in Bourdieu's thought. This is the reason why he includes 'art producers', including Western classical musicians, among the 'ruling classes' ${ }^{96}$ If, however, professional musicians are of low social rank, this highlights a fundamental problem with Bourdieu's association of cultural capital with social and economic hegemony. Other social scientists have already noted related problems with his notion of cultural capital. Frow, for example, by rearranging Bourdieu's own data on musical taste, ${ }^{97}$ demonstrates that his idea of cultural capital (that is to say, expressing a preference for the Well-Tempered Clavier over Rhapsody in Blue or the Blue Danube) does not correlate at all with class structure measured in terms of economic or social power, merely with levels of education, ${ }^{98}$ or what Bourdieu calls educational capital. Given that educational capital for Bourdieu is simply 'accredited cultural capital', this constitutes a completely circular argument. Robinson and Garnier in their turn demonstrate that educational capital is only very weakly linked with social rank. ${ }^{99}$

Part of the problem in trying to establish the social location of musicians is that it is exceptionally rare to find a study that examines both the consumer and the producer in order to establish the relationship between social rank and culture. ${ }^{100}$ Bourdieu's Distinction focuses almost entirely on the relation between taste and the consumer's social rank, which in his case has the unfortunate effect of collapsing the producer into his or her product (which, of course, belongs to the field of production designed by and for the consumer). ${ }^{101}$ On the other hand, studies of musicians' social identities focus largely on the producers' perceptions of their own social rank and rarely provide substantial evidence taken from discussions with their audiences. If, however, one pursues the capitalist analogy, in which class is determined first by relations to the means of production and secondly by relations of authority or control over labour power, it is fairly obvious that professional musicians do not possess cultural capital; musicians are cultural labour. ${ }^{102}$ I would argue further, after Qureshi, that it is our cultural inability to see music as a tangible product of physical labour ${ }^{103}$ that has led to much

95 Joppke, 'Cultural Dimensions of Class Formation', 24.

96 Bourdieu, Distinction, 17.

97 Bourdieu, Distinction, 13-18.

98 Frow, 'Accounting for Tastes', 52-5.

99 Robinson and Garnier, 'Class Reproduction', 146.

100 Ehrlich's The Music Profession being an outstanding exception; for the beginnings of an attempt to address this issue see also Qureshi, 'Confronting the Social'.

101 Bourdieu, Distinction, 231-2.

102 This is not an entirely new point; as Cottrell points out in this issue, a number of writers after Adorno have made analogies between orchestral musicians and labour, but such references have largely remained in the realm of rhetorical whimsy. Adorno does attempt to pin the analogy to social reality in locating musicians among the petty bourgeoisie and endowing them with what he perceived to be stereotypical working-class attitudes and characteristics (Introduction to the Sociology of Music, 110-15). My statement is no analogy.

103 As opposed either to the ephemeral sublime in live performance, or to intellectual property in relation to recorded 
of our confusion over musicians' social location. ${ }^{104}$ Musicians in the Mughal period undoubtedly possessed the status of servants, a point that Ehrlich, Becker, Gillett, and others have also made repeatedly about Western musicians ${ }^{105}$ - occasionally very highly paid and highly admired servants, but servants nonetheless, and the elite treated them as such. They produced cultural capital for their patrons, who both paid the labour to produce what they wanted to hear, and who were the primary beneficiaries of that capital in terms of shoring up their own position.

On the other hand, if we do not accept Bourdieu's equation of cultural capital with elite rank, and argue that cultural capital may be available to any individual or social group, not just to members of the dominant classes, to use as 'a resource of power [. . . ] to improve their positions within the social class structure', ${ }^{106}$ music does function in a sense as cultural capital for musicians, because music enables their liminality. And this liminality, when exploited very carefully, can be used as a means to improve musicians' social and economic standing.

In the Mughal empire, not only did music allow performers to enter elite male spaces and to mingle in close physical proximity with the princes, but, unlike other kinds of servants, they were temporarily granted sanction to exert emotional power over the elite through music and to suggest subversions of the status quo that on other occasions would be unthinkable. These suggestions inhered in the content of most song lyrics and the primary emotional association of music itself - love and the grief of separation from the beloved. Romantic and erotic love was simultaneously one of the most cherished and dangerous of Mughal cultural values. Love, on the one hand, was valorized in the highest of poetical and lyrical forms; but, at the same time, falling in love, like giving in to all extremes of emotion or conduct in both Islamic and courtly prescriptions, was posited as a danger to the nobleman, because love was seen as enslavement to the beloved, leading to the loss of virtue, reason, and rank. Because music was seen as reinforcing love in its power to charm as well as to sway, the danger to the mirza in the musical performance was that he would fall permanently under the performer's power. As long as this prospect was merely flirted with temporarily, the exploration of the power of love in musical sound to pull down barriers of rank and gender provided the ideal atmosphere for the mehfil.

I have argued elsewhere ${ }^{107}$ that the time and place of musical performance, the mehfil, was therefore a liminal space, in which both the low-ranking performers and the elite could momentarily play-act the crossing of social boundaries in a way that both explored the cherished universal theme of Indo-Persian high culture, and acted to diffuse its threat, reinforcing the status quo and preventing these incursions from crossing over into the 'real'

music. In an era of commodification we have no trouble seeing the latter as a product, but the very name intellectual property' gives away our belief that the product stems from the ephemeral creative impulses of the mind, not the technical facilities of the body. As anyone who has done time in an orchestral string section will know, this is not necessarily the case.

104 For an important discussion see Qureshi, 'Confronting the Social', 23-6, 28-9.

105 Ehrlich, Music Profession, 43; Becker, Outsiders, 82; Gillett, 'Ambivalent Friendships', 324-5.

106 Joppke, 'Cultural Dimensions of Class Formation', 25.

107 Brown, 'If Music Be the Food of Love'. 
world. ${ }^{108}$ If the prince successfully negotiated the rules guiding the patron's conduct in the mehfil while managing to flirt safely with the social boundaries of his world, the mirza demonstrated to his peers his high rank and his unshaken power over men and women of low rank.

The boundaries were, however, sometimes crossed in a more permanent manner. The most common way in which threats to the 'real' status quo were manifested was in individual performers' attempts to use their personal liminality permanently to enhance their social rank. For the best musicians, their liminality and the concomitant ambiguity of their social position, particularly when they were showered with praise and wealth, enabled them primarily to disguise and partially to shed their low rank and caste backgrounds. This was often facilitated precisely by the adoption of neutral occupational titles instead of stigmatized caste names, which thereby created a shelter for social elevation in the form of caste mobility. The most famous example is that of the dhadhis (see above), who changed their name four times in as many centuries as an important part of their strategy to transcend their lower status and gain access to the courts. ${ }^{109}$

However, bearing in mind that women who performed in male space routinely offered sexual entertainment, for a female performer to exercise liminality in order to climb the social ladder sometimes meant marrying up, encouraging her patron to fall in love with her and marry her, enabling her to enter the legitimate female space of the haram, to which, as a courtesan, she was forbidden entrance. For the occasional man it meant using one's connections, either social or sexual, to attain the ranks of the nobility. If the Mughal historians are to be believed, the first scenario seems to have happened rather often, despite being frowned upon. The Mughal chronicles and books of etiquette considered both actions to be scandalous and reprehensible for each of the parties involved, and symptomatic of societal decadence.

The possibility of such things happening led to the mehfil being hedged around with all sorts of restrictions aimed at maintaining distance between patron and musician during performances, such as never singing if a musician were present for fear of lowering the mirza's esteem and making him vulnerable to being taken advantage of by social climbers. ${ }^{110}$ Woe betide those noblemen who did not keep sufficient distance, like the mid-eighteenthcentury nobleman Miran: 'because he fraternises with the principal dancers and musicians, and provides a rendezvous for them, [his peers] wholly revile [him]'. ${ }^{111}$ Historical cases of social elevation, such as that of the courtesan Lal Kunwar, who became the favourite queen of one of the emperors, or of her cousin Ni'mat Khan, who used his connections to secure a high rank in the nobility, are treated as cautionary tales, at the end of which terrible sanctions imprisonment, exile, and loss of patronage in this case - are meted out to the transgressors. ${ }^{112}$

108 For a similar conclusion concerning the twentieth-century mehfil, but using different language, see Qureshi, 'Confronting the Social', 30-2.

109 For the history of the dhadhis' strategies for social elevation see Brown, 'Hindustani Music', 154-72, and Neuman, 'Bowing Bards'.

110 Ahmad, 'The British Museum Mirzanama', 101.

111 Dargah Quli Khan, Muraqqa'-i Dehli, 69-70.

112 For the story of Ni'mat Khan's downfall see Brown, 'If Music Be the Food of Love'. 
In many cases the threat of the social climber to the status quo was diffused through satire, such as the nineteenth-century Hindi joke that runs 'His father was a musician, and so was his grandfather; but he says, "Sir! My family is noble!" '. ${ }^{113}$ This joke indicates the power of liminality to provide opportunities for musicians to improve their social rank. At the same time, through ridicule, the joke puts them firmly back in their place. Interestingly, many of these sanctions and jokes involve sexual stigma, especially for the men, who are branded pimps or catamites; while homosexuality was not stigmatized in Mughal society, the passive partner certainly was, and to be labelled a catamite was to have your low and 'deviant' social status marked on your body. ${ }^{114}$

\section{Edgemen and Women: Liminality, Rank, and Cultural Capital}

What I have described here very closely evokes Victor Turner's descriptions of liminality in rituals of status reversal. I shall now use the example of classical musicians in the Mughal empire as a template by which to generalize a more widely applicable hypothesis concerning the social liminality of professional musicians. In order for professional musicians in any particular society to be considered institutionally liminal, at least the first six, and customarily all, of the following conditions should be present (each one will be discussed more fully below):

(1) low occupational rank, which inheres in musicians' status as service professionals; their work may be considered cultural labour, which produces

(2) cultural capital;

(3) this is highly valued and respected by the social elite for its social and aesthetic benefits to them, and

(4) enables the musician to cross normative boundaries of social rank and to enter elite spaces ordinarily closed to members of their community or class;

(5) the moment of performance and the persona of the musician are therefore characterized by a play with social norms and boundaries in a manner that suggests Turner's rituals of status reversal, that is to say, the structural inferiors in the room are temporarily permitted to exercise power over their structural superiors, and may (but not always) play the jester's role of society's conscience; if

(6) the musician is exceptional, he or she may be able to use their liminality to enhance their social and/or economic status on a permanent basis; ${ }^{115}$ on the other hand,

(7) the musician's efforts at social elevation may attract their patrons' resistance and be unsuccessful, leading to

(8) sanctions, which may involve the labelling of musicians as

(9) 'deviant', reinforcing their low occupational rank (see (1) above); the paradox of low occupational rank combined with the high respect given musicians for their art may produce

113 Crooke, Tribes and Castes, vol. 1, p. 497.

114 For a full discussion see Brown, 'If Music Be the Food of Love'.

115 At which point they escape the cycle I am describing here. 
(10) confusion or ambiguity as to their precise social location in modern occupational hierarchies, or a sense that musicians are somehow outside the system altogether.

It is interesting to note the cyclical and reinforcing nature of this paradigm, which has clear resonances with Merriam's tripartite formulation of low status/high importance/tolerance of 'deviance'; indeed, it may be considered an elaboration of it. At the end of this paper I shall highlight the possibility that the nineteenth-century professionalization of musicians that accompanied industrialization and the move from aristocratic to mass middle-class patronage, not only in the West but also in India, may have effected changes to the social location of musicians. But first I shall discuss the wider evidence for the social liminality of musicians as a professional class. Given the enormous amount of relevant secondary literature, I shall attempt to confine my discussion of each condition to one or two examples.

\section{(1) Low occupational rank}

To me popular music is still the voice of the working class, collective rage in a way, though not angst-ridden. But it does really seem like the one sole opportunity for someone from a working class background to step forward and have their say. It's really the last refuge for the articulate but penniless humans. ${ }^{116}$

There is considerable evidence in many societies either that musicians come from low-rank, marginal, or outsider backgrounds, or that the occupational rank of professional musicians is low. Rather than rehearsing the evidence for the importance of outsiders and minorities to mainstream musical life, ${ }^{117}$ I shall concentrate here on evidence that music has traditionally been seen as a profession of the skilled working classes or, at best, the lower middle classes hence an important link with the idea of musicianship as cultural labour. Before the twentieth century the vast bulk of professional musicians in Europe came from one of two backgrounds: families of professional musicians, ${ }^{118}$ or the artisanal classes, for example Johann Quantz, whose father was a blacksmith. ${ }^{119}$ These were joined in the early twentieth century by musicians from lower middle-class and impoverished families, including Lotte Lehman, Rubinstein, and Horowitz. ${ }^{120}$ The low occupational rank of musicians was underscored until at least the 1960s by the fierce and widespread resistance of parents from the established and even lower middle classes to any hint that their children were considering music as a career. ${ }^{121}$ The reasons for this resistance were partly historical: Ehrlich notes that even 'respectable' tradesmen in England in the nineteenth century were encouraged to

116 Morrissey, New Musical Express, December 1984.

117 See, instead, Hooker in this issue. B. Nettl also provides an extensive list of examples (Study of Ethnomusicology, 339-42).

118 See Gelatt, Music Makers, 138, 150; Ehrlich, Music Profession, 11, 48.

119 P. Nettl, Forgotten Musicians, 161, 204, 280.

120 Gelatt, Music Makers, 122, 233, 242-3; the families of the last two were destitute.

121 For twentieth-century examples of parental opposition see Gelatt, Music Makers, 122-3; Horne and Schickel, Lena, 3, 48-9; and Becker, Outsiders, 115. Until almost the start of the twentieth century, English public schools, which provided a private education for middle- and upper-class boys, virtually forbade their pupils to learn music at all; see Ehrlich, Music Profession, 75. 
disdain music as a profession for their children, because 'A Musician, let him be ever so talented and exemplary in moral conduct, ranks scarcely above an ordinary artizan [sic]'. ${ }^{122}$ But the reasons were also to do with music's ongoing status in the twentieth century as a service profession (see Becker below). ${ }^{123}$ In relation to Indian classical music, Qureshi notes that professional musicians continue in some cases to exist in 'conditions of feudal servitude':

For my first teacher to eat at our table was taboo. Though he was served food when we ate, interaction between musicians and 'respectable' people was kept to the strictly musical. Of course, he was paid for his service, like other service people, but how much was determined preemptively by the patron. ${ }^{124}$

(2) Cultural capital that is (3) highly valued by the elite for its benefits to them

Ni'mat Khan: His existence in Hindustan is a blessed gift. He is renowned for his compositions [...] and is on par with the nayaks of bygone days [...] His personal eminence makes him bow only before the Emperor. During the reign of Shah Muhammad Mui'zud-din [Ni'mat Khan] was [...] highly honoured and respected. ${ }^{125}$

Stories of the value placed on and the lionization of the best musicians in many societies are legion. ${ }^{126}$ The value placed on music can often translate into economic wealth for the best performers, but also into more symbolic kinds of capital, such as fame, honorary doctorates, and knighthoods. ${ }^{127}$ Gillett notes that upper-class amateur musicians in nineteenth-century Britain 'revered the [foreign] musicians with whom they socialised' at private concerts and soirées. Nonetheless, the elite primarily engaged these celebrity musicians as 'a statement of power that could be demonstrated by highly conspicuous consumption'. ${ }^{128}$ Van Nieuwkerk notes that in modern Egypt professional musicians and dancers are necessary at all big social functions as 'objects of prestige and competition. The more performers or the more expensive and famous the entertainers, the more prestige the host family gains'. This prestige, however, does not accrue to the performers. ${ }^{129}$ As Qureshi notes:

Feudal patrons [in North India] have music performed for them, even when they are competent to do so themselves - why? [. . .] to have labor performed by others is a fundamental diagnostic of status [...] [His status makes] it necessary for a feudal patron to have music, like other products, produced through the labor of service professionals. ${ }^{130}$

122 Ehrlich, Music Profession, 9, 42, 19.

123 Gillett, 'Ambivalent Friendships', 337; cf. Becker, Outsiders, 82, 115.

124 Qureshi, 'Confronting the Social', 16-17.

125 Dargah Quli Khan, Muraqqa'-e Dehli, 75.

126 For example, Nigeria: Merriam, Anthropology of Music, 133; North India: Bakhle, Two Men and Music, 32-3, 37; Afghanistan: Baily, Can You Stop the Birds Singing, 42, 46.

127 See, for example, Horne and Schickel, Lena, 125; Gelatt, Music Makers, 162; Cottrell, Professional Music-Making, 197.

128 Gillett, 'Ambivalent Friendships', 324-5, 332; see also Ehrlich, Music Profession, 20.

129 Van Nieuwkerk, 'A Trade Like Any Other'.

130 Qureshi, 'Confronting the Social', 31. 
In other words, paying for musicians is a demonstration of the patron's cultural capital and economic power, indicating his superiority in the social structure because he can afford such highly regarded cultural service. As Becker points out, the patron holds all the real power in the relationship because he is always 'in a position to get his way; if he does not like the kind of music played, he does not pay to hear it a second time'. ${ }^{131}$

\section{(4) Cultural capital that enables the musician's extraordinary liminality}

Few occupations offered so many opportunities to cross frontiers of wealth and class which were closed to most people: entering rich households to play and teach, sometimes mingling with the company or even achieving a degree of intimacy with one's betters. In most cases the crossing was temporary and constrained, to be followed by a return from mansion to garret. ${ }^{132}$

In her memoir, Tindall tells a story of accompanying Sam Sanders and Itzhak Perlman to a private soirée on the Upper West Side of New York City. As she ascends in the elevator and arrives in the apartment of the wealthy private patron, there is a strong sense in her narrative of having been permitted a close and somewhat voyeuristic peek into a world of wealth and privilege that she would never otherwise have seen, and in which, although she coveted it, she felt uncomfortable - like a fish out of water - when permitted to socialize with the guests. ${ }^{133}$ Evidence of the crossing of social boundaries allowed to musicians is rife in the literature. Another apt example is Lena Horne, a black woman who found herself performing at all-white clubs and venues 'which even for our engagement still did not allow Negroes to buy tickets'. Later she sang at private parties in the homes of the Mellons and the Carnegies, where she would 'amuse [herself] by taking in the details of how the other half lived', mingling with her hosts. ${ }^{134}$ Despite musicians' low rank, therefore, the desirability of their musical talents allows them to cross over, however temporarily, into their patrons' world.

\section{(5) The liminality of the moment of performance}

Different from the cook, [the Indian musician] is inseparable from his product, the only servant who shares the feudal salon as a full participant in the highest elite events [...] musical performance offers a shared moment of consumption which means entering into personal relationship with the product [...] Here the musician is the master of his product [.. .] he, the servant, takes on the ways of patrons [...] Most important, the musical experience is quite explicitly identified as a shared meal [...] a meal that is created jointly by host and cook. ${ }^{135}$

131 Becker, Outsiders, 89.

132 Ehrlich, Music Profession, 31-2.

133 Tindall, Mozart in the Jungle, 123-4, 130-2.

134 Horne and Schickel, Lena, 74-5, 99. For other examples see P. Nettl, Forgotten Musicians, 280-1; Baily, Music of Afghanistan, 104; and especially Hooker in this issue.

135 Qureshi, 'Confronting the Social', 29-30. 
Cottrell provides a great deal of evidence to support the idea that the Western orchestral concert is indeed a liminal, ritual event, in which 'communitas [...] is an important feature'. ${ }^{136}$ The nature of the musical performance as ritual and, following Turner, in some way a liminal event is the aspect of liminality that has most often been examined in relation to music, and I shall therefore not go into it here. ${ }^{137}$ However, I noted earlier that if musicians do possess an institutionally liminal status, they ought to display some of the attributes characteristic of rituals of status reversal: ambiguity of status, the subversion of society's norms and rules, sanction to speak truth to power, the temporary exertion of power over the powerful, 'ostentation', and 'pseudohierarchy'. ${ }^{138}$ I shall leave the issue of the ambiguity of musicians' social location for now, as well as the idea that musicians subvert society's norms and rules, which is such an important pillar of Merriam's formulation.

On the other points, there is much evidence to support the idea that professional musicians do exhibit many of these characteristics. The role of musicians in many societies as 'court jester' has already been noted, and the use of music for the purposes of protest is prevalent in many societies, from Bob Dylan to Billy Bragg to the Zulu protest singers of South Africa. Because musicians eventually have to conform to their patrons' taste and values or risk losing patronage, in many cases overt musical protest is not possible or even aesthetically desirable, for example in the case of much art music. Merriam noted, however, that 'song texts [in general] can "express deep-seated feelings not permissibly verbalized in other contexts" ',139 an idea that resonates strongly with my evidence of Mughal musical culture. On the subject of wielding power, musicians in many societies have been imbued with apparently magical or supernatural powers (both Paganini and Robert Johnson, for example, are supposed to have sold their souls to the devil). Silver has further noted that modern-day Hindustani musicians are fully aware of the power of music to 'control the devil in man'. ${ }^{140}$ In relation to ostentation and pseudohierarchy, Qureshi's point - that in performances of Hindustani music 'the servant takes on the ways of patrons' - is telling. She notes that 'the art music ensemble offers a replication of the [external] power hierarchy on which the musician depends. The lead musician controls a hierarchical performance structure of soloist over accompanist, singer over instrumentalist, melodic over rhythmic accompanist.'141 Similar pseudohierarchies can be seen at play among Western musicians, both mimicking external social hierarchies (country music for the working classes, classical for the middle and upper classes), ${ }^{142}$ and among ostensibly similar kinds of musician, for example in the cut-throat world of orchestral string sections, in which where you sit is a visible reminder of your place in the pecking order. ${ }^{143}$

136 Cottrell, Professional Music-Making, 156.

137 See instead other contributions to the present issue.

138 Turner, Ritual Process, 200.

139 In Cottrell, Professional Music-Making, 143.

140 Silver, 'The Adab of Musicians', 323.

141 Qureshi, 'Confronting the Social', 30.

142 See Savage and others, 'Cultural Capital in the UK', 31-2. This is an excellent recent study of class and musical taste in Britain, following Bourdieu.

143 Ibbotson, 'Why We Look So Miserable', The Guardian, 16 December 2005. 
(6) Successful social elevation - (7) for the privileged few

For many musicians [their liminality] provided incentives, and for some opportunities, of more permanent social elevation. Such emigrations were hazardous, for few places are less familiar or welcoming than those occupied by an elevated social group, eager to identify and exclude intruders. ${ }^{144}$

Musical performance continues to present some individuals with opportunities to transcend their social or occupational rank more permanently; most of the world's great stars would fall into this category. In discussing her first boyfriend, a talented Latino-African-American violinist from a poor urban background, Tindall reiterates a common cliché: that music may act as a 'ticket out of the ghetto' for members of structurally inferior groups. ${ }^{145}$ For a tiny handful of the best and most socially savvy musicians, this may indeed be possible. Ehrlich lists a number of musicians in eighteenth- and nineteenth-century England who successfully transcended their humble origins, including the propensity of many female singing stars to marry up. ${ }^{146}$ He notes, however, that social success for musicians, 'whether achieved within the profession or by marrying money, required more than musical talents: sensitivity to niceties of social behaviour and confidence to brazen out solecisms, an eye for the main chance'; ${ }^{147}$ in other words, the ability to fake or absorb the values, tastes, and practices of the middle and upper classes. This sensitivity is reflected elsewhere in musicians' attempts to distance themselves from the purportedly 'deviant' behaviour of apparently similar musicians, such as the number of Afghan musicians who, to all intents and purposes, are full-time, paid professional musicians but who nonetheless insist they are 'amateurs'. ${ }^{148}$ Lena Horne insisted that the reason for her band's success with both 'respectable' black and rich white audiences was because 'we were not a typical Negro band [...] we didn't have any of those dope-using, drunken, horrible Negro people of popular lore in our band'. ${ }^{149}$ Like the Indian dhadhis, a number of Jewish popular artists in 1950s America changed their names in order to ensure their success, including Carole King (Klein), and Simon and Garfunkel, who first recorded as Tom and Jerry. ${ }^{150}$ In nineteenth-century Europe, for those with the social skills necessary to pass as 'respectable' and network with one's patrons, it was possible to attain permanent social elevation; George Smart, a fairly undistinguished musician from a humble background, eventually bought himself a knighthood. But even great musicians who lacked social skills, like Samuel Wesley, continued to '[labour] under the disadvantage of the low status that had traditionally been the lot of the profession'. ${ }^{151}$ For the vast bulk of today's musicians, as Philippa Ibbotson has argued, 'there are few vocations that

144 Ehrlich, Music Profession, 31-2.

145 Tindall, Mozart in the Jungle, 27; see also Becker, Outsiders, 115.

146 Ehrlich, Music Profession, 11-15.

147 Ehrlich, Music Profession, 32.

148 Baily, Music of Afghanistan, 101-3.

149 Horne and Schickel, Lena, 65.

150 See Humphries, Boy in the Bubble, 6.

151 Olleson, 'Samuel Wesley', 36. 
demand such long years of training for work that is so poorly paid and devoid of personal responsibility'. ${ }^{152}$

(8) The sanctions of patrons for 'social climbing'

[The term] virtuoso [...] is often used with contempt, especially by composers

[...] virtuosi are commonly believed to occupy an artistic rank somewhere between that of the escape artist and that of the trained seal. ${ }^{153}$

I have not found much evidence in other cultures for the kinds of harsh sanctions meted out in North India to musicians who attempted to climb the social ladder. ${ }^{154}$ However, there is some evidence from the history of Western art music for the kinds of satirical comments about social climbers that in India take the form of jokes and proverbs and are similarly designed to puncture pretensions, tearing through the façade of high rank and reminding both musicians and audiences of the performer's humble beginnings. Gillett, for example, notes that even in relation to top international soloists performing in 'intimate settings in the homes of cultivated music-lovers, incidents could arise that carried memories of the professional musician's formerly servile status'. ${ }^{155}$ George Smart's 'deference and obsequiousness [...] [his] social climbing, his pretensions, and in particular his purchased knighthood came in for Wesley's special scorn', partly out of jealousy at Smart's success, but also because Wesley himself came from the established middle classes. ${ }^{156}$ To return to the modern world of North Indian music: while at the very least public statements about musicians whitewash their backgrounds and are usually wholly reverent, ${ }^{157}$ behind the scenes the courtesan backgrounds of a number of great female musicians and the numerous mistresses of certain great male stars are an open secret, ${ }^{158}$ and are often used to denigrate rivals. It seems that one of the main ways in which society's attempt to contain the liminality of musicians is manifested is through stereotypes of 'deviant' behaviour - stereotypes musicians sometimes live up to.

\section{(9) Being labelled 'deviant'}

As Merriam noted in 1964, the list of societies that award at least some of their musicians low status because of their 'deviant' behaviour, real or ascribed, is a very long one. Van Nieuwkerk argues that the profession of Egyptian dance is in and of itself disreputable and

152 Ibbotson, 'Why We Look So Miserable'.

153 Sachs, Virtuoso, 7.

154 For examples see Brown, 'If Music Be the Food of Love', 80-2. See also Hooker in this issue, whose article also provides important examples of how the structurally dominant exert control over the potentially subversive musicians in their midst, in this case through scholarship and other forms of intellectual expertise. Gillett, 'Ambivalent Friendships', 324-5.

156 Olleson, 'Samuel Wesley', 37. Olleson notes that Wesley's middle-class parents were opposed to him pursuing a musical career (25).

157 Bakhle, Two Men and Music, 37.

158 For an exception that proves the rule see Menon, 'Song on the Breeze', Outlook, 27 December 2004: Menon's obituary of the late great South Indian singer M. S. Subbulakshmi was the only one of many tributes in the national press that mentioned her well-known courtesan background. 
therefore brings its practitioners into disrepute; 159 and Lena Horne noted that the female performers at the Cotton Club where she worked in the 1930s were essentially 'escorts' for the big businessmen and politicians who visited, a practice that was actively encouraged by the club management. ${ }^{160}$ The Afghan Gharibzadeh, considered 'to be of low morals, to be dirty, violent, bad Muslims, stealers of children, practising prostitution', are additionally despised because they act as barbers, which in Afghan society is considered ritually polluting. ${ }^{161}$ The most important discussion of musicians as a 'deviant' group to date, however, is Howard Becker's chapter on American dance-hall musicians in Outsiders: Studies in the Sociology of Deviance. Published a year before Merriam's magnum opus, what he has to say about dance musicians as a group labelled 'deviant' has striking similarities with Merriam's conclusions. He notes that:

Their culture and way of life are sufficiently bizarre and unconventional for them to be labeled as outsiders by more conventional members of the community [...] Feeling their difference strongly, musicians likewise believe they are under no obligation to imitate the conventional behavior of squares [...] Accordingly, behavior which flouts conventional social norms is greatly admired [...] This is more than idiosyncrasy, it is a primary occupational value. ${ }^{162}$

In other words, because musicians perceive themselves to be different, some at least live up to the stereotypes with which their patrons enforce their servant status.

Indeed, the primary way musicians' 'deviance' from the norms of 'respectable' society functions is to underline his or her low or outsider social rank, in a cycle of reinforcements:

Regardless of the social class from which he comes, it is usually obvious to the prospective musician's family that he is entering a profession which encourages his breaking with the conventional behavior patterns of his family's social milieu [...] In the middle-class family, choice of dance music as an occupation is viewed as a movement into Bohemianism, involving a possible loss of prestige for both individual and family, and is vigorously opposed. ${ }^{163}$

Whether low occupational rank or 'deviant' behaviour came first in this cycle can only be a matter of speculation, but I would argue that it was the musician's rank as a servant:

The dance musician [...] is a member of a service occupation and the culture he participates in gets its character from the problems common to service occupations [...] [which are] distinguished by the fact that the worker in them comes into more or less direct and personal contact with the ultimate consumer of the product of his work [...] Consequently, the client is able to direct [...] the

159 Van Nieuwkerk, 'A Trade Like Any Other'.

160 Horne and Schickel, Lena, 48-50.

161 Baily, Music of Afghanistan, 102-3.

162 Becker, Outsiders, 87 (my emphasis).

163 Becker, Outsiders, 115. 
worker at his task and to apply sanctions of various kinds, ranging from informal pressure to the withdrawal of his patronage. ${ }^{164}$

(10) Confusion or ambiguity as to musicians' precise social location

[The status of music as a profession is] the most undefined and vague [...] [a musician may be] an itinerant fiddler, and of the lowest grade of society; or a man of the highest attainments, moving in the most exclusive circles. ${ }^{165}$

In her autobiography, Lena Horne reflected sadly on 'the cruelty you encounter as a Negro who is also leading a gypsy's life in a profession that is not particularly respectable in the eyes of many people'. However, in the very next paragraph she recalled that 'we were the first Negro orchestra to play the roof of the Ritz-Carlton' in Boston. ${ }^{166}$ It is hard to find a better statement of musicians' experience of the paradox of institutional liminality than this. Indeed, as Cottrell notes, a great deal of puzzlement and ambiguity remains in many societies concerning musicians' social location. ${ }^{167}$ A peculiarly British crisis of domestic etiquette ensued in the late nineteenth century as to musicians' place in the overall social hierarchy, centring on 'their place of reception and entertainment [and] misgivings as to whether the small drawing-room, the lower library, or servants' hall, [should] be appropriated for their accommodation'. ${ }^{168}$ This bourgeois confusion over the exact occupational rank of the professional musician was at least partly symptomatic of 'the emerging shape of the new industrial society', which, as Ehrlich points out, required 'a class structure in which the status of occupations was clearly defined. Where was the profession of music to fit?'. ${ }^{169}$

\section{Where? Shoehorning Musicians into the Hierarchies of Advanced Capitalism}

The late nineteenth and early twentieth centuries saw the professionalization of musicians along standard industrialized lines - accreditation through systematic examinations, college and university courses and degrees, and unionization - paralleling the growth of industrialization, market capitalism, and the rise of the middle classes, and spurred on by the felt need of the new, status-conscious middle-class audience to 'respectabilize' musicians and/or classical music and to pin down once and for all their ambiguous rank. Whether this acted to increase the social rank of music as a profession requires further study. That this occurred in both Western Europe and India at roughly the same stage in their modernization, and that it resulted in both cases in a steady increase of men and women from middle-class backgrounds entering the profession in the twentieth century, with a concomitant rise in social approval

164 Becker, Outsiders, 82.

165 Byerly Thomson, 1857, in Ehrlich, Music Profession, 43.

166 Horne and Schickel, Lena, 67.

167 Cottrell, Professional Music-Making, 193.

168 Ehrlich, Music Profession, 43.

169 Ehrlich, Music Profession, 50. 
for such a move, ${ }^{170}$ suggests that this is a possibility. ${ }^{171}$ Zukin has noted a similar phenomenon in relation to visual artists in the United States, who, prior to the Second World War, were considered bohemian, suspect, and of low social rank, but who, through a massive injection of state funding for the arts after the war, were for the first time integrated into mainstream society as part of what she describes as the broad middle classes. Spurred on by a stated desire to 'respectabilize' a 'problematic' group of workers by forcing them into the class structure as 'service-sector' professionals, state support for the arts, which involved 'cleaning up' the reputation of artists, led to the visual arts being transformed into a legitimate career for the middle classes and particularly for women. ${ }^{172}$

Zukin, interestingly, has noted that photographic technology and the delegation of art commissioning to agents around 1900, which decreased opportunities for artists to mingle directly with their traditional patrons, and then the embourgeoisement in the 1960s of the artistic professions themselves, ${ }^{173}$ led to a decrease in the liminality of artists as the class status of patron and artist converged. This decrease in liminality can also be seen in the history of North Indian classical music in the early twentieth century, in which the desire of the middle classes to 'respectabilize' classical music was spurred on not so much by class as by the desire of Hindus, who constituted the vast majority of the British-educated middle classes, to take the future of a music co-opted as a symbol of Indian nationalist pride out of the hands of the so-called 'decadent' Muslim hereditary musicians, who were accused of letting it decline. ${ }^{174}$ An ideologically driven sense of duty led a number of upper-caste, upper middle-class Indians, including such luminaries as Ravi Shankar, to take up classical music professionally, ${ }^{175}$ a trend that increased over the century to the point where the majority of top musicians are now probably Hindu. The fate of Muslim hereditary musicians, on the other hand, bifurcated. Those who managed to maintain their position as top performers and teachers, often in part by gaining audiences and often residence in the West, ${ }^{176}$ accepted the values of the new middle-class audiences and modified their performances and their musicological discourse accordingly. ${ }^{177}$ Those who did not, particularly traditional courtesans ${ }^{178}$

170 A parallel process also occurred in Iran from the 1960s, concomitant with the institutionalization of music training. I am indebted to Laudan Nooshin for this information (personal communication 2006).

171 Compare the modernization of the music profession in Britain from the mid-nineteenth to the early twentieth centuries (Ehrlich, Music Profession, ch. 4 onwards) with India from the late nineteenth to mid-twentieth centuries (e.g. Bakhle, Two Men and Music, chs 1, 2, and 6, bearing in mind that Bakhle's assessment of some of her earlier evidence is hampered by a lack of knowledge of previous eras; her claim that the mehfil was an invention of early twentieth-century nostalgia, for example, is wholly incorrect).

172 Zukin, 'Art in the Arms of Power', 424-5, 435-7, 441, 443-5.

173 Zukin, 'Art in the Arms of Power', 433, 435-7.

174 See, for example, Capwell, 'Marginality and Musicology', 234, 238-9; Bakhle, Two Men and Music, 94-5.

175 See Shankar's autobiography, My Music, My Life.

176 For example, the families of the great sitarists Ustad Vilayat Khan and Ustad Imrat Khan, who live in the UK and the US.

177 The Muslim Dagar brothers, for example, insist on the Sanskrit and Hindu foundations of their musical practice, something that Widdess argues has more to do with contemporary India-Pakistan politics than personal conviction ('Festivals of Dhrupad', 93).

See Maciszewski in this issue. 
and performers of low-prestige instruments such as the sarangi, ${ }^{179}$ found their liminality severely restricted as their opportunities for performance in higher-ranking spaces declined. Once you have, on the one hand, middle-class performers playing for middle-class audiences, and, on the other, those traditional performers who do not conform to middle-class values restricted to lower-status spaces, social liminality can no longer exist in musical performance to quite the same extent.

With regard to Western art music in the United States and the United Kingdom since the Second World War, state funding for the arts, which included subsidizing the training of musicians from their first primary-school lessons to music college, led to a massive increase in the number of professional musicians, ${ }^{180}$ but no corresponding increase in the audience for classical music, and a substantial decline in private infrastructures for patronage and training. The inevitable and ideologically motivated collapse of state support in Britain in the 1980s, under Margaret Thatcher, and 1990s, especially the removal of subsidized instrumental teaching from state schools, therefore meant that the large number of working-class and lower middle-class children who had been enabled to enter the profession through state support found it much more difficult. Although some state funding has been restored, ${ }^{181}$ currently only those children whose parents can afford private music lessons and instruments, and for whom both education and classical music are an important part of their cultural values - in other words upper middle-class children, especially girls ${ }^{182}$ - can attain the levels of musical competence required for admission to the still state-funded music colleges, which since the war have become the sole training ground for professional classical musicians. The empirical work required to demonstrate that there has been a shift in the class backgrounds of classical musicians since the Second World War, and particularly since the 1980s, is yet to be done, but recent official figures on the intake into British music colleges make provocative reading. Compared with the national average for British universities of 87 per cent of intake coming from state schools and 28 per cent from working-class backgrounds, only 56.8 per cent of the Royal Academy of Music's intake comes from state schools, worse than those bastions of privilege Oxford and Cambridge, and just 5 per cent from working-class backgrounds. Statistics for the Royal College of Music are even worse, with a state school intake of 45 per cent and no return on the figure for working-class students. ${ }^{183}$ Overall, the figures demonstrate that the music colleges are the most exclusive higher education institutions by student social background in the United Kingdom.

179 For details of sarangi players' plight see Qureshi, 'The Indian Sarangi', and Magriel, 'The Sarangi in North Indian Music'.

180 See Tindall, Mozart in the Jungle, 156; Ehrlich, Music Profession, 231.

181 See Curtis, 'Music Lessons "Dominated by Middle-Class Girls"', The Guardian, 22 October 2004. Nonetheless, the author notes that 'despite there being fee remission for the extra-curricular classes, most of which require a parental contribution, students from poorer backgrounds are less likely to ask for, or be encouraged to take, music lessons'. In 2006 the state funding situation in the UK was again looking precarious; see Ibbotson, 'Teach our Kids to Play', The Guardian, 24 February 2006.

182 Curtis, 'Music Lessons'.

183 'Widening Access Rates', The Guardian, 30 September 2004; Higgins, 'Discordant Note', The Guardian, 4 October 2004. The figures are similar for pre-1992 higher education institutions; for details see Nicola Dibben’s important report on 'Music and Social Class' in higher education. 
The situation with commercial popular music is slightly different, because it has never been seen as 'necessary' to gain a qualification or even to take private music lessons in order to become a rock star; there are still plenty of self-taught singers, guitarists, and drummers at the top of the profession, and, according to anecdotal evidence, it seems that popular musicianship is now more widely encouraged in schools than previously. ${ }^{184}$ Moreover, with a few notable exceptions such as Dido, James Blunt, and Coldplay - and again the evidence here is largely anecdotal ${ }^{185}$ - most popular artists still seem to come from working-class backgrounds and have therefore maintained their social-class (and often ethnic) liminality throughout the twentieth century. The middle-class exceptions, however, might be pointing to an interesting new future: popular music has long definitively replaced classical music as the soundtrack of choice for middle-class youth. ${ }^{186}$

Whether, since the early twentieth century, these changes in the class background of people entering the profession has in fact changed the occupational rank, and therefore the liminality, of professional musicians remains unclear, however. There is evidence to suggest that the occupational rank of professional musician in the United States and the United Kingdom remains low in the twenty-first century regardless of the social background of the performer, although this of course may change. Cottrell notes continuing resistance among British middle-class parents in 2004 to accept their children's (particularly their sons') choice to become professional musicians; ${ }^{187}$ my own parents did not want me to become a professional musician; and Tindall's experience that classical music is not, after all, a 'glamorous' or 'elite' career, but is instead 'overpopulated, stagnant' and 'low-paying', and these highly trained, highly gifted artists are 'miserable', 'peripheral', 'irrelevant', not respected, unemployed, insecure, and 'unemployable', 188 is echoed in a number of recent British newspaper columns on the parlous state and working conditions of London's orchestral musicians. ${ }^{189}$ In other words, the social location of professional musicians today, as we should expect, still seems to be something of a puzzle. But I would argue that this final evidence suggests that the backgrounds from which professional musicians are recruited are irrelevant to the location of the profession itself, and that its location has not yet significantly altered. In the words of the feted North Indian vocalist Asghari Bai, 'the melodious voice who once held millions in her thrall', 190 who in her old age lives forgotten in penury like so many other once-famous North Indian musicians:

184 I am grateful to Laudan Nooshin for this observation (personal communication 2006); see also Duddell, 'Letters', The Guardian, 4 March 2006.

185 I have been unable to find any quantitative research that examines the social backgrounds of popular musicians to corroborate this commonly held view; I am grateful to Dai Griffiths for confirming the limited nature and ambiguity of the existing evidence (personal communication 2006).

186 See Savage and others, 'Cultural Capital in the UK', 31-2.

187 Cottrell, Professional Music-Making, 193.

188 Tindall, Mozart in the Jungle, 303-6.

189 For example, Ibbotson, 'Why We Look So Miserable'; see also Cottrell, Professional Music-Making.

190 Wadhwa, 'A Song of Penury', Outlook, 29 January 1997. 
I want the [government] to take back my Padma Shri! ${ }^{191}$ I'll barter it for two square meals a day. I've discovered my family can't lick it when they're starving [...] [My music] got me meetings with Indira (Gandhi) and a picture with the President. But it didn't help get my family [bread]. ${ }^{192}$

\section{Bibliography}

Abul Fazl. Ain-i Akbari, ed. H. Blochmann, vol. 2. Bibliotheca Indica, new ser. Calcutta: Baptist Mission Press, $1876-7$.

Adorno, Theodor W. Introduction to the Sociology of Music, trans. E. B. Ashton. New York: Seabury, 1976.

Ahmad, Aziz, trans. 'The British Museum Mirzanama and the Seventeenth Century Mirza in India'. Iran: Journal of the British Institute of Persian Studies 8 (1975), 99-110.

Baily, John. Music of Afghanistan: Professional Musicians in the City of Herat. Cambridge: Cambridge University Press, 1988.

- 'Can You Stop the Birds Singing?' The Censorship of Music in Afghanistan. Copenhagen: Freemuse, 2001.

Bakhle, Janaki. Two Men and Music: Nationalism in the Making of an Indian Classical Tradition. New York: Oxford University Press, 2005.

Bashford, Christina, and Leanne Langley, eds. Music and British Culture: Essays in Honour of Cyril Ehrlich. Oxford: Oxford University Press, 2000.

Becker, Howard S. Outsiders: Studies in the Sociology of Deviance. New York: Free Press, 1963.

Bhabha, Homi K. The Location of Culture. New York and London: Routledge, 1994, repr. 2004.

Blake, Stephen. Shahjahanabad: the Sovereign City in Mughal India, 1639-1739. Cambridge South Asian Studies 49. Cambridge: Cambridge University Press, 1991.

Bourdieu, Pierre. Distinction: a Social Critique of the Judgment of Taste, trans. Richard Nice. Cambridge, MA: Harvard University Press; London: Routledge \& Kegan Paul, 1984.

Brown, Katherine Butler. 'Hindustani Music in the Time of Aurangzeb'. PhD diss., University of London, School of Oriental and African Studies, 2003.

. 'If Music Be the Food of Love: Masculinity and Eroticism in the Mughal Mehfil', in Love in South Asia: a Cultural History, ed. Francesca Orsini. Cambridge: Cambridge University Press, 2006. 61-83.

_ _ 'Did Aurangzeb Ban Music? Questions for the Historiography of his Reign'. Modern Asian Studies 41/1 (2007), 77-120.

Capwell, Charles. 'Marginality and Musicology in Nineteenth-Century Calcutta: the Case of Sourindro Mohun Tagore', in Comparative Musicology and the Anthropology of Music: Essays on the History of Ethnomusicology, ed. Bruno Nettl and Philip V. Bohlman. Chicago: University of Chicago Press, 1991. 228-43.

Chandra, Satish. 'Cultural and Political Role of Delhi, 1675-1725', in Delhi through the Ages: Essays in Urban History, Culture and Society, ed. R. E. Frykenberg. Delhi: Oxford University Press, 1986. 205-17.

Cottrell, Stephen. Professional Music-Making in London: Ethnography and Experience. London: Ashgate, 2004.

Crehan, Kate. Gramsci, Culture and Anthropology. London: Pluto, 2002.

Crooke, William. The Tribes and Castes of the North-Western Provinces and Oudh, 4 vols. Calcutta: Government Printing Office, 1896.

Curtis, Polly. 'Music Lessons "Dominated by Middle-Class Girls"”. The Guardian, 22 October 2004.

Danielson, Virginia. The Voice of Egypt: Umm Kulthum, Arabic Song, and Egyptian Society in the Twentieth Century. Chicago: University of Chicago Press, 1997.

Deagon, Andrea. 'Dancing at the Edge of the World: Ritual, Community and the Middle Eastern Dancer'. Arabesque, September 1994. <http://people.uncw.edu/deagona/raqs/dancing_at_the_edge.htm> (accessed 1 November 2006).

Dibben, Nicola. 'Music and Social Class: Implications of Widening Participation in Higher Education for Student Experience of Teaching and Learning in Music'. Summary of a project funded by a PALATINE Development Award, Sheffield, September 2004.

Doubleday, Veronica. Three Women of Herat. London: Cape, 1988.

Duddell, Joe. 'Letters'. The Guardian, 4 March 2006.

Ehrlich, Cyril. The Music Profession in Britain since the Eighteenth Century: a Social History. Oxford: Clarendon Press, 1985.

191 The fourth-highest civilian honour bestowed by the Government of India.

192 Wadhwa, 'A Song of Penury'. 
Emigh, John, and Ulrike Emigh. 'A Joker in the Deck: Hajari Bhand of Rajasthan', in J. Emigh, Masked Performance: the Play of Self and Other in Ritual and Theatre. Philadelphia: University of Pennsylvania Press, 1996. 207-43.

Faqirullah Saif Khan. Tarjuma-i-Manakutuhala \& Risala-i-Rag Darpan [1666], ed. Shahab Sarmadee. New Delhi: Indira Gandhi National Centre for the Performing Arts, and Motilal Banarsidass, 1996.

Frow, John. 'Accounting for Tastes: Some Problems in Bourdieu's Sociology of Culture', in Pierre Bourdieu, ed. Robbins. Vol. 3, pp. 44-58.

Gelatt, Roland. Music Makers: Some Outstanding Musical Performers of Our Day. New York: Alfred A Knopf, 1953.

Gennep, Arnold van. The Rites of Passage, trans. Monika B. Vizedom and Gabrielle L. Caffee. London: Routledge \& Kegan Paul, 1960.

Gillett, Paula. 'Ambivalent Friendships: Music-Lovers, Amateurs, and Professional Musicians in the Late Nineteenth Century', in Music and British Culture, ed. Bashford and Langley. 321-40.

Hasan, Qazi. Sarud al-Bahr [1663]. Hyderabad, Salar Jung Museum Library. Persian Manuscript, Mus. 8, f. $1 \mathrm{~b}-14 \mathrm{a}$.

Higgins, Charlotte. 'Discordant Note over “Too Posh” Academy'. The Guardian, 4 October 2004.

Honneth, Axel. 'The Fragmented World of Symbolic Forms: Reflections on Pierre Bourdieu's Sociology of Culture', in Pierre Bourdieu, ed. Robbins. Vol. 3, pp. 3-19.

Horne, Lena, and Richard Schickel. Lena. London: Andre Deutsch, 1966.

Humphries, Patrick. The Boy in the Bubble: a Biography of Paul Simon. London: Sidgwick \& Jackson, 1988.

Ibbetson, Denzil. Panjab Castes [1916]. Delhi: Low Price Publications, 1999.

Ibbotson, Philippa. 'Why We Look So Miserable'. The Guardian, 16 December 2005.

—. 'Teach our Kids to Play'. The Guardian, 24 February 2006.

Joppke, Christopher. 'The Cultural Dimensions of Class Formation and Class Struggle: on the Social Theory of Pierre Bourdieu', in Pierre Bourdieu, ed. Robbins. Vol. 3, pp. 20-43.

Kamran, Mirza. 'The Mirzanamah (the Book of the Perfect Gentleman) of Mirza Kamran with an English Translation' [c. 1672], ed. and trans. Mawlavi M. Hidayat Husain. Journal of the Asiatic Society of Bengal 9 (1913), 1-13.

Khan, Dargah Quli. Muraqqa'-e Dehli: the Mughal Capital in Muhammad Shah's Time [1739-41], trans. Chander Shekhar and Sharma Mitra. Delhi: Deputy, 1989.

—. Muraqqa'-i Dihli [1739-41], ed. Khaliq Anjum. New Delhi, 1993.

Khan, Khafi. Muntakhab al-Lubab [finished 1734]. In Aurangzeb in Muntakhab-al-Lubab, ed. Anees Jahan Syed. Bombay: Somaiya, 1977.

Khan, Mirza. Tohfat al-Hind [c. 1675]. Oxford, Bodleian Library. Persian Manuscript, Elliott 383.

Khan Rasikh, Inayat. Risala-i Zikr-i Mughanniyan-i Hindustan [1753], ed. Syed Ali Haider. Patna: Arabic and Persian Research Institute, 1961.

Kippen, James. The Tabla of Lucknow: a Cultural Analysis of a Musical Tradition. Cambridge: Cambridge University Press, 1988.

Koskoff, Ellen. Women and Music in Cross-Cultural Perspective. Urbana and Chicago: University of Illinois Press, 1989.

Magriel, Nicholas. 'The Sarangi in North Indian Music'. <http://www.sarangi.net/> (accessed 1 November 2006).

Menon, Sadanand. 'Song on the Breeze'. Outlook, 27 December 2004. <http://www.outlookindia.com/ full.asp?fname $=$ Subbulakshmi\%20(F)\&fodname=20041227\&sid=1> (accessed 11 September 2006).

Merriam, Alan P. The Anthropology of Music. Evanston, IL: Northwestern University Press, 1964.

Miner, Allyn. Sitar and Sarod in the Eighteenth and Nineteenth Centuries. Delhi: Motilal Banarsidass, 1993.

Morrissey. New Musical Express, December 1984, in 'No Dad, I Won't Be Home Tomorrow: a Smiths and Morrissey Website'. <http://www.compsoc.man.ac.uk/ moz/quotes/chatter.htm> (accessed 11 September 2006).

Nettl, Bruno. The Study of Ethnomusicology: Twenty-Nine Issues and Concepts. Urbana and Chicago: University of Illinois Press, 1983.

Nettl, Paul. Forgotten Musicians. New York: Philosophical Library, 1951.

Neuman, Daniel. The Life of Music in North India: the Organization of an Artistic Tradition. Detroit: Wayne State University Press, 1980.

_. 'Bowing Bards (Dhadhi, Mirasi, Manganiar, and Langa)', in Essays on the History of North Indian Music, ed. Joep Bor, Françoise Delvoye, Jane Harvey, and Emmie te Nijenhuis. New Delhi: Manohar (forthcoming).

Nieuwkerk, Karin van. 'A Trade Like Any Other': Female Singers and Dancers in Egypt. Austin: University of Texas Press, 1995. <http://www.utexas.edu/utpress/excerpts/exvantra.html> (accessed 1 November 2006).

Olleson, Philip. 'Samuel Wesley and the Music Profession', in Music and British Culture, ed. Bashford and Langley. 23-38. 
Porter, Dennis. 'Orientalism and its Problems', in The Politics of Theory: Proceedings of the Essex Conference on the Sociology of Literature, July 1982, ed. Francis Barker, Peter Hulme, Margaret Iversen, and Diana Loxley. Colchester: University of Essex, 1983. 179-93.

'Profile: George Weah'. BBC website, 11 November 2005.<http://news.bbc.co.uk/1/hi/world/africa/4403120.stm> (accessed 1 November 2006).

Qureshi, Regula. 'The Indian Sarangi: Sound of Affect, Site of Contest'. Yearbook for Traditional Music 15 (1997), $1-37$.

—. 'Confronting the Social: Mode of Production and the Sublime for (Indian) Art Music'. Ethnomusicology 44/1 (2000), 15-38.

Rice, Timothy. May It Fill your Soul: Experiencing Bulgarian Music. Chicago: University of Chicago Press. 1994.

Robbins, Derek, ed. Pierre Bourdieu, 4 vols. London: SAGE, 2000.

Rolfe, Lionel Menhuin. The Menuhins: a Family Odyssey. San Francisco: Panjandrum, 1978.

Robinson, Robert V., and Maurice A. Garnier. 'Class Reproduction among Men and Women in France: Reproduction Theory on its Home Ground', in Pierre Bourdieu, ed. Robbins. Vol. 1, pp. 144-73.

Russell, Dave. 'Musicians in the English Provincial City: Manchester, c. 1860-1914', in Music and British Culture, ed. Bashford and Langley. 233-53.

Sachs, Harvey. Virtuoso. London: Thames \& Hudson, 1982.

. Arthur Rubinstein: a Life. London: Phoenix, 1997.

Said, Edward. Orientalism: Western Conceptions of the Orient. London: Routledge \& Kegan Paul, 1978.

Sanyal, Ritwik, and Richard Widdess. Dhrupad: Tradition and Performance in Indian Music. London: Ashgate, 2004.

Savage, Mike, Modesto Gayo-Cal, Alan Warde, and Gindo Tampubolon. 'Cultural Capital in the UK: a Preliminary Report Using Correspondence Analysis’. CRESC Working Paper Series, No. 4. Manchester: CRESC, University of Manchester, 2005. <http://www.cresc.man.ac.uk/downloads/wp1to30/wp4.pdf> (accessed 11 September 2006).

Shankar, Ravi. My Music, My Life. New York: Simon \& Schuster, 1968.

Sharar, Abdul Halim. Lucknow: the Last Phase of an Oriental Culture, ed. E. S. Harcourt and Fakhir Hussain. Delhi: Oxford University Press, 1994.

Silver, Brian. 'The Adab of Musicians', in Moral Conduct and Authority: the Place of Adab in South Asian Islam, ed. Barbara Metcalf. Berkeley: University of California Press, 1984. 315-29.

Sorrell, Neil, and Ram Narayan. Indian Music in Performance: a Practical Introduction. Manchester: Manchester University Press, 1980.

Tindall, Blair. Mozart in the Jungle: Sex, Drugs and Classical Music. London: Atlantic, 2005.

Turner, Victor. The Ritual Process: Structure and Anti-Structure. London: Routledge \& Kegan Paul. 1966.

- The Anthropology of Performance. New York: PAJ, 1987.

Viswanathan, T., and Matthew Harp Allen. Music in South India: Experiencing Music, Expressing Culture. New York and Oxford: Oxford University Press, 2004.

Wade, Bonnie C. Imaging Sound: an Ethnomusicological Study of Music, Art, and Culture in Mughal India. Chicago: Chicago University Press, 1998.

Wadhwa, Soma. 'A Song of Penury'. Outlook, 29 January 1997. <http://www.outlookindia.com/ full.asp? fname $=$ spotlight $\&$ fodname $=19970129 \&$ sid $=1>($ accessed 11 September 2006).

Widdess, Richard. 'Festivals of Dhrupad in Northern India: New Contexts for an Ancient Art'. British Journal of Ethnomusicology 3 (1994), 89-109.

'Widening Access Rates'. The Guardian, 30 September 2004.

Williams, Raymond. Marxism and Literature. Oxford: Oxford University Press, 1977.

Zukin, Sharon. 'Art in the Arms of Power: Market Relations and Collective Patronage in the Capitalist State'. Theory and Society 11/4 (1982), 423-51. 